\title{
A CONSTITUIÇÃO DE CÁDIZ DE 1812 E O NOVO CONSTITUCIONALISMO LATINO-AMERICANO - UMA BREVE ANÁLISE DO CONSTITUCIONALISMO LATINO-AMERICANO EM SUAS ORIGENS ${ }^{1}$
}

\author{
Heleno Florindo da Silva ${ }^{2}$ \\ Daury Cesar Fabriz ${ }^{3}$
}

\begin{abstract}
Resumo
A presente pesquisa se desenvolve com objetivo de analisar o contexto de formação da Constituição de Cádiz de 1812, em seus aspectos mais elementares, tais como o processo de debate através das Cortes de Cádiz, bem como a necessidade de se formatar uma ideia de Nação política, esteio através do qual o novo Estado espanhol seria erguido, a partir de uma aproximação (onde se é possível) ou distanciamento (onde não se é possível) com as novas tendências constitucionais latino-americanas que surgem nas últimas décadas no contexto político, social, econômico e cultural latino-americano, com o objetivo de identificar, nesses cenários um espírito libertário da diversidade, através de um processo dialógico, a ser desenvolvido entre o Eu e o Outro, na formação de uma sociedade mais plural, mais solidária, principalmente em momentos como os atuais, em que a moralidade, a civilidade do ser humano são postas de lado.
\end{abstract}

Palavras-chave: Constituição de Cádiz; Novo Constitucionalismo Latino-Americano; Espírito Libertário; EstadoNação; Sul Global.

\section{INTRODUÇÃO}

Vivemos ${ }^{4}$ um contexto latino-americano, constitucionalmente revolucionário, como a muito tempo não

\footnotetext{
${ }^{1}$ Artigo apresentado como requisito de cumprimento dos créditos na disciplina de Teoria da Constituição, do Programa de PósGraduação Strictu Sensu - Doutorado - em Direitos e Garantias Fundamentais da Faculdade de Direito de Vitória.

${ }^{2}$ Membro do Grupo de Pesquisa Estado, Democracia e Direitos Fundamentais, do Programa de Pós Graduação Stritu Sensu da Faculdade de Direito de Vitória (FDV). Membro da Diretoria Executiva da Academia Brasileira de Direitos Humanos (ABDH). Doutorando em Direitos e Garantias Fundamentais pela Faculdade de Direito de Vitória (FDV). Professor do Curso de Direito e da Pós-Graduação Lato Senso da Faculdade Multivix (Cariacica/ES). Coordenador Geral do Curso de Direito da Faculdade Multivix (Cariacica/ES).E-mail - hfsilva16@hotmail.com.

${ }^{3}$ Mestre em Direito pela Universidade Federal de Minas Gerais. Coordenador do Programa de Pós-Graduação Stritu Sensu em Direitos e Garantias Fundamentais (Mestrado) da Faculdade de Direito de Vitória. Coordenador do Grupo de Pesquisa Estado, Democracia Constitucional e Direitos Fundamentais. Presidente da Academia Brasileira de Direitos Humanos (ABDH). Professor e Advogado. E-mail - daury@terra.com.br.

${ }^{4}$ Como ponto de referência para a construção do presente texto será usada linguagem pessoal, na primeira pessoa do plural, haja vista o objetivo do presente trabalho ser compreender a necessidade de "nós", latino-americanos, observarmos nossas peculiaridades enquanto diversidade epistemológica, algo refletido na Filosofia do Direito Latino-americana, em diálogo com o paradigma euro-norte americano de cariz colonizador. Desta feita, em que pese o melhor estilo de construção narrativometodológica, ser o impessoal, por tais motivos, optou-se pelo presente estilo de narrativa.
} 
se vê no mundo. Constituições como a Brasileira, de 1988, a Colombiana de 1991, a Venezuelana de 1999, a Equatoriana de 2008 e, sobretudo, a Boliviana de 2009, marcam bem o cenário de transformação pelo qual o constitucionalismo latino-americano vem passando nas últimas décadas, a ponto dessas novas tendências constitucionais ficarem conhecidas pela alcunha de novo constitucionalismo latino-americano.

E é nesse cenário de efervescência constitucional e de movimentos constitucionais, pautados na ideia de diversidade, de diferença, que a necessidade de voltarmos a Cádiz se faz presente, haja vista a Constituição de Cádiz dar início, como se discutirá abaixo, a um processo constitucional até então desconhecido na Europa, qual seja, um processo em que "não europeus" puderam fazer parte, mesmo que, como veremos no ponto 3 , esses "não europeus" também fossem representantes de uma determinada parcela social.

Assim, objetivando analisar todo esse contexto latino-americano atual a partir $\mathrm{d}$ uma perspectiva histórica, objetivou-se alcançar reposta ao seguinte problema de pesquisa: a partir dos movimentos que desencadearam a construção da Constituição de Cádiz de 1812, é possível extrair desse contexto histórico o embrião de uma perspectiva revolucionária, pautada em um debate entre os diferentes, ou seja, num processo dialético de construção da realidade, de onde se possa perceber a ideia de libertação da diversidade (filosófica, politica, econômico-social), ínsita as novas tendências constitucionais latino-americanas, fruto do que se $\underline{\text { convencionou chamar de novo constitucionalismo latino-americano? }}$

Para alcançarmos resposta ao presente problema de pesquisa, buscamos, através de uma perspectiva metodológica que se pauta no Múltiplo-dialético ${ }^{5}$, desenvolver, num primeiro momento, o contexto histórico de surgimento e desenvolvimento do processo revolucionário de onde se extraiu a Constituição de Cádiz de 1812, principalmente em relação ao diálogo que esteve presente, neste contexto, entre a Metrópole Espanhola representativa do Norte Global Dominante - e as Colônias Espanholas - representativas do Sul Global Subalterno.

Já no segundo ponto do trabalho, buscamos aprofundar os debates iniciais, compreendendo o que

\footnotetext{
${ }^{5} \mathrm{O}$ paradigma múltiplo-dialético pode ser compreendido desde sua matriz grega, até a contemporaneidade, como o modelo de racionalidade capaz de possibilitar a existência de inúmeras realidades que, mesmo sendo diferentes entre si, convivem em harmonia dentro de uma mesma realidade político-social, ou seja, é o que nos possibilitará perceber a multiplicidade de existência e de modos de compreensão possíveis, bem como a compreensão de que está tudo inter-relacionado, de que tudo o que existe está ligado a ponto de ser especial para a vida em harmonia. É neste sentido que Krohling apontará para o fato de que desde sua formação mais incipiente, na Grécia antiga, a perspectiva do múltiplo dialético ser um importante marco na ascensão e promoção do debate sobre quaisquer situações, o que possibilitará, não só o surgimento, mas a necessidade de sua realização prática, do que hoje chamamos de diferença ou, mais recentemente, de diversidade, pois segundo ele "Os gregos já tinham saído da mitologia, pois viviam a presença de um novo marco, isto é, a realidade da pólis, que modificou profundamente a sua maneira de ser e viver. [...] a ágora (praça pública) é o principal espaço e instrumento de poder. Nesse cenário descendências monárquicas, origens divinas da natureza e explicações mitológicas do poder não têm mais guarida. [...] tudo é debatido. As pessoas agora são iguais. Não há mais hierarquia absoluta e muito menos monarquia. [...]. Esse é o marco inicial. Não há nada que não possa ser discutido. Não existem mais verdades eternas (2014, p. 23-24)". Em decorrência do espaço limitado de um artigo científico, para um aprofundamento acerca do método do Múltiplo Dialético, ver KROHLING, Aloísio. Dialética e Direitos Humanos - múltiplo dialético: da Grécia à Contemporaneidade.Curitiba: Juruá Editora, 2014. Cap. 4.
} 
chamamos de "espírito libertário" da pluralidade presente nas Cortes de Cádiz, atrelando a esse debate, a construção da ideia de Nação como algo, aparentemente, contraditório aos debates revolucionários desencadeados em Cádiz.

Por fim, na terceira parte, analisamos como as novas tendências constitucionais latino-americanas podem ser compreendidas ao analisarmos e buscarmos compreender todo o processo desencadeado em Cádiz, principalmente no que se chamou no segundo ponto d discussão, de "espírito libertário" daqueles que, atém então, não se faziam representar no Estado e, via de consequência, em seu governo, como agentes de Direitos, mas, tão somente, como agentes de deveres.

Assim, não se buscará, em toda essa pesquisa, conforme se percebe, compreender o processo político, social e filosófico desenvolvido pelas Cortes de Cádiz, que deram origem a Constituição de 1812, para além daquilo que efetivamente representou para, por exemplo, o contexto latino-americano (o que se debaterá terceira parte do trabalho), mas, tão somente, analisar esses eventos como chave de leitura para entendermos os esforços, após o apogeu das Cortes de Cádiz, objetivando silenciar a Constituição lá produzida.

A Constituição de Cádiz, neste sentido, pode ser um importante instrumento para a compreensão de um movimento revolucionário, que fugiu ao padrão até então conhecido para o desenvolvimento constitucional de um Estado e que, em decorrência disso, teve de ser silenciada e violentada de todas as formas, fato que nos chama atenção, ao analisarmos os novos movimentos constitucionais latino-americanos que objetivam se construir, assim como em Cádiz, para além de modelos pré-estabelecidos ou de conceitos previamente pactuados.

\section{A FORMAÇÃO DA CONSTITUIÇÃO DE CÁDIZ DE 1812 - UMA ANÁLISE DE SEU CARÁTER REVOLUCIONÁRIO A PARTIR DO DIÁLOGO COM AS COLÔNIAS DO SUL}

Conforme salientado, já na introdução deste trabalho, antes de entrarmos na Constituição de Cádiz de 1812, e analisa-lo em suas especificidades que lhe destacam de outras Constituições da época, alguns apontamentos se fazem necessários com o fim de chamar a atenção para o fato de que não se trata de uma Constituição qualquer.

Diante disso, nós podemos perceber que só pelo fato de seu processo de construção ter sido, para época, um processo revolucionário, pois como veremos, o texto se dá através de uma "assembleia" composta por representantes, não somente da metrópole espanhola, mas, também, de todas as colônias latino-americanas, de modo que a Constituição de Cádiz de 1812, não é, como muito se diz, uma simples cópia da Constituição francesa de 1791, marco das Revoluções que marcaram o Séc. XVIII Francês, e que culminaram com a queda da Batilha (evento que designa o ápice da Revolução Francesa) em 1789. 
Portanto, a Constituição de Cádiz de 1812 se distancia, dentre outros aspectos, da Constituição Francesa da época, também, pelo fato dessa última, ter sido fruto, como visto, de um processo revolucionário, que se desenvolveu internamente, e cujo objetivo mais premente era colocar fim àquilo que se conhecia como regime absolutista de Estado, cujo maior representante francês fora Luiz XVI, "O Rei Sol”, ou seja, modificar o sistema social e político da época, e acabou instaurando, como fruto da revolução, uma República (1792).

Assim, é preciso marcarmos o contexto histórico em que a Constituição Espanhola de 1812 se desenvolve, a fim de tracejar as suas principais características que fazem dela uma importante peça para o desenvolvimento do Constitucionalismo Latino-Americano, mesmo que ainda fosse, no momento de sua construção, um constitucionalismo, como veremos abaixo, de matriz europeia, uniformizador e homogeneizante.

$\mathrm{Na}$ busca por contextualizar, historicamente, os eventos que vão marcar o surgimento da Constituição Espanhola, portanto, é importante frisar que a Espanha fora, nos anos anteriores, invadida por um exército estrangeiro (França), que lhes impôs um outro governante, escolhido pelo então governo Francês, o que deflagrou uma dupla resistência aos espanhóis, pois, se de um lado e com a ajuda inglesa ${ }^{6}$, combatiam com as armas o inimigo, o invasor francês, de outro, combatiam as ideias, para um novo regime, que fosse estabelecido não a partir das escolhas do governo francês invasor, mas pelos próprios espanhóis.

É aí que surge a importância de Cádiz, geograficamente protegida dos inimigos, tal como uma fortaleza, possibilitou que tudo o que antecedeu a elaboração final da Constituição de Cádiz de 1812, fosse possível sem que os inimigos franceses pudessem, naquele momento, interferir em seus desígnios, dissolvendo o processo revolucionário que se gestava em Cádiz, mas que se tinha iniciado na Ilha de León, em setembro de $1810^{7}$.

\footnotetext{
${ }^{6}$ Sob essa ajuda de que falamos, é importante destacar que se tratou de uma pequena, mas não desinteressada - de ambos os lados - ajuda, tendo em vista que a Espanha se encontrara "praticamente sozinha" no contexto do conflito com a França, mas não poderia correr o risco de criar um "novo" e poderoso inimigo, a Coroa Inglesa, motivo esse, que pode ser compreendido como uma das justificativas que a levou a se aproximar dos ingleses nesse período. Em relação a atuação dos ingleses nesse contexto não se dar de forma contundente, pois se o contexto era de guerra se esperava tiros de canhão e batalhas marítimas ou terrestres, Bethell nos apontará que a Inglaterra, aproveita o momento de fragilidade espanhola, para se aproximar do mercado da colônias, ou seja, como meio de troca a seu apoio frente aos movimentos de insurreição latino-americanos, bem como frente ao governo espanhol de origem francesa, a Inglaterra quer ver reconhecida que "[...] qualquer tentativa de restringir o seu comércio corrente poderia resultar no imediato reconhecimento das novas nações e aconteceria o mesmo diante de alguma interferência estrangeira pela força ou por ameaça" (2001, p.250)", ou seja, não exigiu que a Espanha lhe reconhecesse apta ao comércio com suas colônias, movimento esse seguido, mais tarde por outros Estado, tais como a "[...] A Prússia, na década de 1820, estava entabulando vínculos comercias cada vez mais estreito com a América espanhola. [...] a Prússia trocou agentes comercias com o México e, em 1827, assinou um acordo semelhante aos estabelecido entre o México e a França. Seguiu-se a isso a negociação de um tratado comercial, que na verdade representou o reconhecimento da independência do México [...]. (2001, p.256).

${ }^{7}$ Conforme de debaterá abaixo, mas já adiantando alguns pontos da importância de Cádiz para o processo revolucionário espanhol dos fins do séc. XVIII e início do séc. XIX, importantes são as palavras de Bezerra, que destaca que o início dos debates desenvolvidos e aprimorados em Cádiz, foi a llha de Léon, pois “[...] em setembro de 1810, na Isla de León, reuniram-se os deputados espanhóis de ambos os hemisférios - Espanha, América e Ásia - em Cortes Gerais e Extraordinárias. A seu passo, em comitiva, para uma missa prévia na Iglesia de San Pedro e depois para o teatro do lugar, onde começaria sua reunião inaugural, uma grande multidão acolhia-os com aplausos, vivas, flores e panfletos com canções patrióticas. Menos de seis meses depois de começados os trabalhos constituintes, em 20 de fevereiro de 1811, as Cortes mudaram-se para o Oratório de San Felipe Neri, na
} 
As várias reuniões, assembleias, que se realizariam em Cádiz, e que posteriormente ficariam conhecidas como as Cortes de Cádiz, tinham como objetivo central a laboração de um documento, forjado por espanhóis e para os espanhóis, que tivesse, portanto, força bastante para frente às imposições vindas do governo napoleônico através do que se chamou Estatuto de Bayona ${ }^{8}$, que se concretizou em uma espécie de Carta Constitucional, cuja finalidade era subjugar o povo espanhol a um governo vindo e escolhido pelo imperador francês.

Assim, a Constituição de Cádiz de 1812 nasce de um desejo espanhol de manter, de recuperar a soberania, não somente uma soberania como a ideia de algo que demarca a superioridade de um tipo de governo no âmbito interno de um Estado, mas, e principalmente, a soberania dos espanhóis em decidir quem é, ou faz parte, desse governo soberano, ou seja, de não se submeter à direção, sem legitimidade, de nenhuma outra autoridade, monárquica ou republicana ${ }^{9}$, fosse ela espanhola ou estrangeira.

É o que pode ser compreendido logo pelas determinações dos artigos da Constituição de Cádiz, que marcam a ideia de que a Nação Espanhola é que detém a soberania do Estado - tal fato demonstra a influência de Jean Jacques Rousseau, e sua principal obra, "O Contrato Social", também no processo revolucionário espanhol da época - ou seja:

Art. 20 - A Nação Espanhola é livre e independente, e não é, nem pode jamais ser patrimônio de família, ou pessoa alguma.

Art. $3^{\circ}$ - A soberania reside essencialmente na Nação, e por isso a essa pertence exclusivamente o direito de estabelecer suas leis fundamentais ${ }^{10}$.

Portanto, o processo revolucionário de Cádiz, pode e deve ser compreendido como algo ínsito à realidade Espanhola da época, e não simplesmente como uma transmutação de um modelo a outra realidade, em que pesem as claras influências de autores, como vimos, que também foram importantes para outros processos revolucionários, tais como Montesquieu e Rousseau.

cidade de Cádiz, que oferecia melhores condições de segurança ante o suposto perigo de iminente bombardeio da ilha pelo exército invasor napoleônico" (2013, p. 102-103).

${ }^{8}$ Segundo Dallari, o Estatuto de Bayone ou Carta Outorgada, foi uma espécie de Constituição, outorgada por Napoleão Bonaparte aos Espanhóis, através de José Bonaparte, seu irmão, e que, por aquele fora elevado - conforme se verá abaixo - ao posto de Rei da Espanha, e que falava ao povo espanhol, quais seriam as regras para a estruturação do Estado Espanhol a partir do reinado de José Bonaparte, sendo que, conforme preceitua Dallari, "para a grande maioria dos espanhóis o Rei verdadeiro era Fernando VII e a Constituição autêntica deveria ser elaborada pelos espanhóis, dois pontos fundamentais que estiveram na base de movimentos de rebeldia em várias partes da Espanha, em uma verdadeira «guerra de independência», que levaria à Constituição de Cádiz em 1812" (2014, p. 86).

${ }^{9}$ Conforme veremos abaixo, os espanhóis que se figuraram como constituintes nas Cortes de Cádiz tiveram a oportunidade de optarem pela forma de governo que a Espanha passaria a ter - monarquia ou república -, optando por darem continuidade à monarquia, mas de um modo completamente distinto daquela que até então marcara o Estado Espanhol, pois, passaram a reconhecer um papel limitado ao Rei, posto que no tocante ao novo regime de separação de poderes - algo que pode ser visto como influência de autores importantes do contexto revolucionário francês, tal como Charles Louis Secondat, conhecido como "o Barão de Montesquieu” - princípio este que fora explicitamente reconhecido na Constituição Espanhola de 1812, nos artigos 15 ("o poder de fazer as leis reside nas Cortes com o Rei"); 16 ("o poder de fazer executar as leis reside no Rei") e 17 ("o poder de fazer aplicação das leis, tanto nas causas civis, quanto nas criminais, reside nos Tribunais estabelecidos pela lei”), as funções do ausente Fernando VII ficavam reduzidas praticamente a dar cumprimento às leis emanadas das Cortes, representantes da Nação. 
A Espanha, através de Cádiz e da Constituição de 1812, fez sua própria e peculiar revolução ${ }^{11}$, pois tais processos guardam em si aspectos não só políticos, mas, também, sociais, econômicos e, sobretudo, culturais, o que, evidentemente, se distingue de sociedade para sociedade ${ }^{12}$.

Outro ponto que marca o incrível caráter revolucionário da Constituição de Cádiz de 1812 é seu caráter de ser, na época, a Constituição que teve o processo de elaboração mais plural - o que posteriormente, como veremos mais adiante, se transformou em um empecilho para os governos espanhóis, o que levou a Constituição de Cádiz a ser suprimida várias vezes, num processo de encobrimento, desvelamento, de suas matrizes - dentre as Constituições (das mais conhecidas até então, as Francesas (1791 13) e a Americana (1787)), pois possibilitou que os povos das Colônias Espanholas (mesmo que não em sua integralidade, como veremos) se fizessem representar em Cádiz, sendo, por isso, possível afirmar que a Constituição de Cádiz é mais universal que a francesa (COHEN e BUENO, 2008).

O contexto revolucionário de construção da Constituição de Cádiz, portanto, fora tão importante no

\footnotetext{
${ }^{10}$ Neste ponto, Dallari nos informa que a Constituição de Cádiz “[...] fugindo da tradição absolutista [...] adotou a Monarquia com limitações, [...]. E a soberania nacional foi considerada atributo da Nação, não do Rei” (2014, p. 90).

${ }^{11}$ Diante disso, é importante frisarmos, como já discutido, a influência de autores e outros contextos revolucionários, para a questão espanhola ora em debate, tais como os autores e o contexto revolucionário francês do final do século XVII. Contudo, embora a Revolução Francesa e o apogeu de Napoleão, por exemplo, possam ter influenciado nos desdobramentos dos acontecimentos revolucionários na Espanha, a cadeia de atos insurgentes levada a cabo pelos espanhóis - a partir de 1808 e que culminou em 1812, com a Constituição de Cádiz - de modo algum se decorreu em um espírito que se subsuma a uma Constituição adjetivada de uma mera "xérox" dos desdobramentos revolucionários franceses. Tal situação, inclusive, é prontamente reconhecida por dois dos maiores estudantes do processo revolucionário espanhol que deu origem a Constituição de Cádiz, Marx e Engels, para quem "La Constitución de 1812 ha sido tachada, por un lado [...] de ser una mera imitación de la francesa de 1791, trasladada a suelo español por visionarios, sin tener en cuenta las tradiciones históricas de España. [...] Lejos de ser una copia servil de la constitución francesa de 1791, fue un vástago genuino y original de la vida intelectual española, que regeneró las antiguas instituciones nacionales, que introdujo las medidas de reforma clamorosamente exigidas por los autores y estadistas más célebres del siglo XVIII, que hizo inevitables concesiones a los prejuicios populares" (MARX e ENGELS, 1998, p. 136-139). Neste interim, é importante destacar que Marx e Engles buscaram compreender a Constituição de Cádiz de 1812 e todo o processo revolucionário que a desencadeou, pois consideravam-no importante para a compreensão de outros desdobramentos futuros que ocorreram na Espanha. Assim, Bezerra destaca que "Marx e Engels tiveram grande interesse pela Espanha, conheciam sua história. Marx começou a estudar espanhol em 1850 ou 1852 e liadiretamente autores espanhóis, como Jovellanos, Blanco White ou José Maria Toreno. Escreveu, como cronista político, uma série de artigos (Spain Revolutionary) no jornal americano New York Daily Tribune, que era o mais influente dos Estados Unidos então e superava, em tiragem, os mais prestigiosos do mundo, como o Times, de Londres" (2013, p. 92 e 93). Pedro Ribas também vê essa busca de Marx e Engels como algo a se perceber, pois, segundo ele, "entre mayo y septiembre de 1854 la dedicación a España pasó, en palabras del propio Marx, de ser una 'ocupación secundaria' a ser 'mi estudio principal” (1998, p. 18), chegando à conclusão, inclusive, segundo Ribas, que "No es exagerado decir que no hay cosa en Europa, ni siquiera en Turquía, ni la guerra en Rusia, que ofrezca al observador reflexivo un interés tan profundo como España en el presente momento [... A Acaso no haya otro país, salvo Turquía, tan poco conocido y erróneamente juzgado por Europa como España" (MARX, 1854 apud RIBAS, 1998, p. 18).

${ }^{12}$ Neste sentido, é importante destacar que um dos marcos iniciais do processo revolucionário espanhol - em que pese não percebermos a história de forma linear, afinal, "a história não pode ser encerrada entre os muros de uma classificação" (HERRERA FLORES, 2009b, p.105) - pode ser compreendido em 2 de maio de 1808, ficando conhecida como La Guerra de la Independencia.

${ }^{13}$ Segundo Quijada Mauriño, "na verdade, seis foram as Constituições francesas anteriores à de Cádiz, cada uma delas com uma definição política própria: 1791 (Monarquia temperada), 1793 (Primeira República), 1795 (Diretório), 1799 (Consulado), 1802 (Consulado perpétuo) e 1804 (Império). Mas costuma-se fazer referência à inaugural, de 1791, pois foi a que fundou as bases das que viriam depois (2008, p. 16).
} 
contexto do desenvolvimento do constitucionalismo da época, através de suas marcas libertárias, que Marx e Engels, conforme destacado acima, se debruçaram em seu estudo, chegando, segundo Ribas, tal discussão a ocupar suas principais discussões, ou seja, [...] comienza a ocuparse de la Constitución de Cádiz, a la que dedica un análisis bastante minucioso (1998, p. 43), percebendo Marx e Engels que a Constituição de Cádiz de 1812 pode e deve ser vista como [...] una constitución moderna, que pone a España a la cabeza de Europa em varios aspectos legislativos (MARX e ENGELS, 1854 apudRIBAS, 1998, p. 43).

Contudo, é importante destacar que não é possível identificar e compreender o que significou o processo constitucional de onde se extraiu a Constituição de Cádiz sem se contextualizar as circunstâncias históricopolíticas, socioeconômicas e culturais da época, que nos ajudará a analisar os eventos revolucionários que marcam o constitucionalismo espanhol da época, mesmo sabendo que o espaço de uma pesquisa como a presente, torne essa contextualização falha em alguns pontos.

A partir de então, é importante destacar o fato de que durante o período revolucionário, que compreendemos como Revoluções Burguesas, dentre as quais se destaca, evidentemente (até mesmo pela proximidade com o território Espanhol e da coroa espanhola) o período francês, que se deu entre os séculos XVIII e XIX, o Estado Espanhol, caracteristicamente monárquico e absolutista, evitou, ao máximo, se contagiar dos ideais libertários dessas revoluções ${ }^{14}$.

Mas com a ascensão de Napoleão Bonaparte ao poder, bem como por suas tentativas de dominação e conquista de um maior número de territórios, o que se deu não só dentro do território continental da Europa, mas, também, através do domínio dos mares, e cujos os objetivos imperiais o marcariam, para sempre, na história, como uma das figuras mais insignes da estória recente da humanidade, a Espanha passou a sofrer, no final do séc. XVIII e início do séc. XIX, profundas transformações, que se deram, sobretudo, na tentativa de manutenção de suas possessões coloniais ultramarinas, pois, segundo Bezerra, Napoleão:

\footnotetext{
${ }^{14}$ Sobre esse período conturbado da monarquia espanhola, Dallari nos informa que "Com a morte de Carlos III, em 1788, a Coroa do Reino espanhol foi herdada por seu filho, Carlos IV, podendo-se dizer que aí começa uma fase de intensas perturbações que acabaram levando à Constituição de Cádiz. De fato, a sucessão não foi tranquila, pois o novo rei, casado com a italiana Maria-Luísa de Parma, era despreparado e desinteressado das questões do governo, que, na prática, ficou nas mãos de Manuel Godoy, favorito da esposa de Carlos IV e continuador das práticas autoritárias de Carlos III. Ocorreram, então rebeliōes populares, com apoio de grande parte da nobreza, contestando-se a legitimidade do governo, pois quem realmente governava era Godoy, e reclamando-se a restauração da legalidade. Em consequência dessas rebeliōes, em 1808 Carlos IV foi forçado a abdicar em favor de seu filho, o que se formalizou no dia 19 de março, passando a Coroa da Espanha a Fernando VII. Essa nova sucessão também não restabeleceu a normalidade reclamada, pois além da fraca personalidade do novo monarca havia forte pressão da França, já governada por Napoleão Bonaparte, que havia sido Primeiro Cônsul e em 1804 se autoproclamara Imperador. Napoleão pretendia expandir o império francês, inclusive dominando a Espanha, o que teve sérias consequências sobre a evolução política espanhola. E a personalidade de Fernando VII facilitou a ingerência francesa no governo da Espanha. Segundo os registros históricos, o novo Rei era despreparado, apático e desinteressado do governo, além de pessoalmente frágil, pois segundo os registros «pesava mais de 100 quilos e tinha voz aflautada». Tudo isso contribuiu para uma série de mudanças no governo da Espanha e para que se radicalizassem as manifestações reclamando a legitimidade do governo e o respeito a limitaçōes legais e aos direitos fundamentais dos espanhóis" (2014, p. 85).
} 
[...] com planos imperialistas, enfrentava a Inglaterra pelo domínio dos mares - o poder marítimo espanhol havia sido solapado na Batalha de Trafalgar (1805) -, o rei Carlos IV e seu ministro, o válido Godoy não tiveram mais saída que a de deixar de lado a neutralidade e tomar partido. Como a Inglaterra era uma fonte inesgotável de problemas para as possessões espanholas na América, a Espanha acabou aderindo à França republicana e, em 1807, Godoy assinou com Bonaparte o Tratado de Fontainebleau, pelo qual se permitia a entrada das tropas francesas em território espanhol (onde seriam alimentadas e mantidas), com a finalidade de invadir Portugal, aliado da Inglaterra (2013, p. 94).

Contudo, a entrada dos soldados franceses, autorizados formalmente a se alocar em território espanhol, começou se percebida como um ato político cujos meios escolhidos a um determinado fim, não foram efetivamente, os melhores, ou seja, deflagrando-se naquilo que o dito popular chama de "o tiro que saiu pela culatra", pois quando os espanhóis de Madrid, Pamplona, Burgos, Valladolid, San Sebastián e Barcelona, entre outras, que receberam os soldados franceses, percebem que os mesmos, com sua presença cada vez mais custosa, indesejada e hostil ao povo espanhol, não iriam, ou não pretendiam deixar o território espanhol ${ }^{15}$, sente-se que aquela presença, portanto, configurava muito mais uma ocupação do exército de mais de cem mil soldados franceses, do que, propriamente, um auxílio político-militar de um país a outro.

Esse sentimento de traição ${ }^{16}$ de seus governantes do povo espanhol a época, principalmente dos membros da nobreza e clero espanhol, chegou ao ápice com a tentativa de fuga da família real para o território da Andaluzia, o que se mostrou desastroso para o então Rei espanhol Carlos IV, que a essa altura se viu retirado do governo espanhol através de um verdadeiro golpe de estado conduzido, sobremaneira, pela nobreza e pelo clero espanhol, que em seu lugar, através do que ficou conhecido como o Motim de Aranjuez, de 17 e 18 de Março de 1808, perpetrou a abdicação forçada de Carlos IV, da coroa espanhola em favor de seu filho Fernando VII, conhecido como o Príncipe de Astúrias (DALLARI, 2014, p. 85).

Contudo, foi nesse mesmo contexto em que Fernando VII, príncipe de Astúrias, reconhecido pelo povo espanhol como seu legítimo governante, que Napoleão Bonaparte, a partir desse enfrentamento flagrante, entre

\footnotetext{
${ }^{15}$ Nesse contexto de percepção do povo espanhol dos maus desígnios de seus governantes, também se destaca, nas palavras de Bezerra, o fato de que a política do ministro Godoy, que, "[...] com suas tentativas de reformas, já vinha ameaçando os privilégios da aristocracia, fez nascer um tal descontentamento no clero e na nobreza que não tardou o surgimento de uma oposição disposta a convencer o príncipe Fernando a conspirar contra o rei, seu pai” (2013, p. 95).

${ }^{16}$ Sobre esses fatos, importantes são as palavras de Bezerra que chega à conclusão de que "menos de dois meses depois, em 2 de maio de 1808, o povo, vendo que toda a família real abandonava o palácio, começou, aos gritos de "traição! traição!", uma sublevação contra os franceses” (2013, p. 95), sendo que essa revolta se estendeu para todo o território espanhol, o que posteriormente ficou marcado como o início do que viu-se acima como a Guerra da Independência (1808-1814). Complementando tal contexto histórico, Dallari assevera que em seguida a tais fatos, e sobretudo, por terem os representantes da coroa espanhola se deslocado para Bayonne à presença de Napoleão Bonaparte, deixando em Madrid, uma Junta Suprema do Governo do Reino, presidida pelo infante Antônio "[...] muitos representantes das Juntas Provinciais da Espanha, que aspiravam pela restauração da independência espanhola, também foram para Bayonne, acreditando poder influir para a reconquista da independência e a adoção de uma Constituição. Entretanto, manifestações violentas em várias cidades espanholas, sobressaindo-se as de Aranjuez e Madri, precipitaram os acontecimentos e o marechal francês Joachin Murat, casado com a irmã de Napoleão Bonaparte e ajudante de ordens do Imperador, foi designado por Napoleão Presidente da Junta Suprema de Governo da Espanha” (2014, p. 86), substituindo, assim, o antigo comando daquela primeira Junta do Governo do Reino.
} 
pai e filho, pela coroa espanhola, convocou, toda a família real espanhola, à sua presença, na região de Bayona ${ }^{17}$, momento em que os forçou a realizar a abdicação da coroa, em favor de seu irmão, José Bonaparte, em maio de 1808, fato histórico que ficou conhecido como as "Abdicações de Bayona"18.

Assim, o território da França passou a ser o território de morada - para uns, forçada, para outros, negociada - da família real espanhola, enquanto que o Estado Espanhol era gerido, como uma verdadeira conquista, pelos desígnios do Imperador Francês, que, buscando dar legitimidade a seus atos, outorgou um arremedo - conforme visto acima - de Carta Constitucional, que ficaria conhecido, nos termos delineados do Dallari, e destacados nesta pesquisa, como Estatuto de Bayona, que concedeu ao povo espanhol, um conjunto de princípios, organizadores de um regime político que poderia ser visto como moderadamente liberal ${ }^{19}$, sendo que após essa outorga, em julho de 1808, José I (José Bonaparte, irmão de Napoleão Bonaparte) iniciou seu reinado espanhol (DALLARI, 2014, p. 86-87; BEZERRA, 2013, p. 95-97).

É importante destacar, a partir de então que de outro lado, os espanhóis, oponentes à dinastia dos Bonaparte, através das abdicações de Bayonne, já vinham se reunindo desde o início de 1808 no que ficou conhecido como Juntas Soberanas, Juntas Supremas ou, simplesmente, Juntas Provinciais, por várias cidades espanholas ${ }^{20}$.

\footnotetext{
${ }^{17}$ Sobre esse momento de imposição das vontades de Napoleão Bonaparte frente a coroa espanhola, Dallari acrescenta que "Por imposição de Napoleão Bonaparte, em Abril de 1808 Fernando VII deslocou-se para Bayonne, deixando em Madrid uma Junta Suprema de Governo do Reino, presidida pelo infante Antônio. [...]. Em 15 de Junho de 1808 instalou-se a Junta de Bayonne, mas Napoleão já tinha programado um conjunto de decisões, que deveriam ser formalmente aprovadas pela Junta para serem apresentadas e aplicadas como expressões da vontade do povo espanhol. Um dos pontos básicos da pauta elaborada por Napoleão era uma sequência de abdicações. Para dar legitimidade a José Bonaparte como Rei da Espanha, Fernando VII, que era o titular da Coroa, apresentou sua abdicação, em favor de seu pai, Carlos IV, de quem fora sucessor. Logo em seguida Carlos IV abdicou novamente, desta vez em favor de José Bonaparte, que foi então apresentado como legítimo detentor da Coroa da Espanha, pela vontade do povo espanhol. Segundo alguns registros históricos, para obtenção das abdicações houve uma negociação prévia. Carlos IV, que era detestado pelos espanhóis, recebeu autorização para viver na França, além de uma pensão vitalícia e Fernando VII recebeu um majestoso castelo na cidade de Valençay, situada no centro da França, longe da fronteira com a Espanha, recebendo também uma pensão vitalícia. Terminado o ritual das abdicações, Fernando VII foi transportado, ou desterrado, segundo alguns, para Valençay, onde permaneceu até quando, em decorrência das decisões de Cádiz, como adiante será exposto, retomou a Coroa da Espanha e assumiu o governo, em 1814" (2014, p. 85 e 86).

${ }^{18}$ Assim, nas palavras de Bezerra, a família real espanhola, os Bourbon, "[...] sem a mínima oposição, transferiram a Napoleão seus direitos dinásticos. Depois disso, instalaram-se os pais, na companhia de Manuel Godoy, em Compiègne. E os filhos, Fernando VII e seus irmãos, no Castelo de Valençay" (2013, p. 95).

${ }^{19}$ Segundo Fernández Sarasola, mesmo que o Estatuto de Bayona tenha sido, formalmente, o primeiro texto constitucional espanhol e, consequentemente, de todos os territórios da hispano-américa, não merece ser levada em consideração, pois, outorgada como fora, mesmo havendo traços de um regime liberal, tratava-se da tentativa de se institucionalizar, em terras espanholas, um governo autoritário (2006, p. 93-99). Contudo, conclui o autor, que o Estatuto de Bayona deve ser destacado sim, como a chama que faltava para incendiar o povo espanhol na busca por uma revolução que transformasse seu Estado (2006, 106-107), ou seja "La Constitución de Cádiz es una respuesta a la bandera del reformismo izada por los franceses con la Constitución de Bayona. Cádiz es la respuesta a Bayona" (SANCHEZ-ARCILLA BERNAL, 2002, p. 109).

${ }^{20}$ Para Bezerra, essas juntas poderiam ser vistas como "[...] organismos compostos por aqueles que, não tendo aceitado a forçada abdicação dos Bourbon, consideravam que a existência de um vazio de poder - na ausência do legítimo Fernando VII - legitimavaos a autoproclamaram-se cidadãos soberanos" (2013, p. 96). É importante destacar, neste sentido, que a primeira destas juntas a se organizar, foi a Junta da região das Asturias, por onde o povo de lá, conforme se percebe nos relatos históricos da época, "[...]
} 
Em uma clara tentativa de subverter a ordem política posta por José I, as diversas Juntas Provinciais, espalhadas por todo Território espanhol, quase todas denominadas "supremas", organizaram-se, em setembro de 1808, em Aranjuez, para compor, depois de várias propostas, e em adoção das ideias vindas da Junta Sevilhana, a Junta Central, que, de início estaria acumulando os novos Poderes Executivo e Legislativo da Espanha (até então ocupados pelo inimigo francês, mas que em seguida nomearia uma Regência haja vista a ausência do então Rei Fernando VII.

Entretanto, no embate de força entre as Juntas, através da Junta Central, e o governo de José I, até mesmo em decorrência de uma questão político-militar, houve total domínio dos franceses (BEZERRA, 2013, p. 102103), fato que fora substancial e elementar para que os espanhóis, não suportando ser tratados como "mais uma nação conquistada dos franceses", decidissem se reunir em Cortes a partir de 1810, a fim de forjar uma Constituição própria, o que se deu com a convocação, pela Junta Central espanhola, em janeiro de 1810.

A Junta Central - que de modo algum poderia ser vista como um grupo homogêneo, pois era composta por vários nichos políticos espanhóis distintos, tais como: os absolutistas, os liberais e os reformistas moderados, diferentes na política espanhola, mas unidos em prol da retomada do Estado frente ao julgo francês - convocou reunião de Cortes, de onde se dissolveu a Junta Central, em surgimento de um Conselho de Regência, esse que, convocou para 24 de setembro de 1810, Cortes Gerais e Extraordinárias a serem realizadas em Cádiz - que, conforme visto acima, era um reduto a que as tropas de José I, então Rei da Espanha, não tinham conseguido chegar - e que pode ser compreendida, segundo Dallari, como "[...] verdadeira assembleia constituinte, que iria elaborar a Constituição aprovada em 1812 e que teria muita influência na história da Espanha" (2014, p. 88).

Essas não seriam Cortes estamentais, e sim nacionais, uma vez que foi a Nação Espanhola que se fez

destituíram do poder as autoridades legalmente constituídas, por meio de um confronto que durou mais de quinze dias. Reunidos em 25 de maio de 1808 na sala capitular da Catedral de Oviedo, fizeram a leitura pública de um documento mediante o qual se estabelecia uma "suprema Junta de gobierno con todas las atribuciones de la soberanía", que se comprometia a lutar pela liberdade e independência da Nação, contra a infame agressão do imperador dos franceses" (BEZERRA, 2013, p. 97). O que fora muito bem compreendido pelo Pérez Garzón ao destacar esse momento histórico como o momento onde o povo espanhol para a perceber que "La soberanía reside siempre en el pueblo", conforme dizia o supracitado documento, que acabou, por assim dizer, em deslegitimar a luta pelo poder do Estado entre famílias ou dinastias, ou seja, entre os Bourbon e os Bonaparte (PÉREZ GARZÓN, 2012, p. 31-32), dando à nação, e não mais às famílias ou a figura do soberano real, o patamar de pilar de sustentação ou de representatividade da unificação do Estado. Sobre essa característica, Dallari nos diz que o casamento de dois Reis Católicos (Fernando de Aragão e Isabel de Castela), fora um dos importantes marcos no processo de formação do Estado espanhol, (catolicismo viria, inclusive, a estar presente na Constituição de Cádiz de 1812, no art. 12, como a religião que, perpetuamente, seria a de todos os espanhóis), sendo que, tal fato, não teria efeitos duradouros a longo prazo, pois mesmo a ideia dos dogmas do catolicismo do casal sendo importante instrumento de unificação do povo espanhol, pois proporcionou, pela primeira vez, a ideia de unidade do Reino Espanhol, "[...] entretanto, não tinha solidez e efeitos práticos, sendo importante assinalar que nos séculos dezessete e dezoito a busca dessa unidade aparece como aspiração dos diferentes centros políticos da Espanha, pois vários fatores impediam sua consecução. A par de muitas disputas pela sucessão dos reis, a Igreja Católica era poderosa e independente, acumulando enorme patrimônio, tendo renda muito elevada e gozando de poder temporal, que usava para interferir nas relações sociais e também para objetivos políticos. A forma tradicional de governo era a monarquia absoluta, mas diferentes reinos, principados e províncias, além de estamentos privilegiados como a nobreza e o clero, eram obstáculos à unidade da Espanha" (2014, p. 84). 
presente nessa assembleia, sem estamentos, que, segundo Pérez Garzón "deu o grito de liberdade” (2012, p. 51). Assim, mesmo que houvessem características comuns em relação ao caráter de nobreza ou clérigo, dos presentes às Cortes de Cádiz, haviam profundas diferenças frente a outros processos constituintes conhecidos a época, tais como o francês e o americano (dominados, eminentemente, por aqueles que faziam parte de um único nicho social de classe e território), pois as Cortes de Cádizforam compostas por representantes da Espanha continental, da Espanha peninsular e insular (incluídas as Filipinas) e, pela primeira vez na história do constitucionalismo moderno, por representantes dos domínios espanhóis na hispano-américa ${ }^{21}$.

É importante destacar neste sentido, que após o estabelecimento das Cortes em Cádiz e do início das discussões para a formação do Texto da Constituição gadatina, foi-se escolhido uma comissão, entre os presentes, cujo fim era a construção de um texto base a partir do qual, as votações pudessem se dar de forma mais eficaz. Essa comissão fora composta por nove integrantes, a partir dos quais é possível se perceber a diferença do processo constituinte desenvolvido em Cádiz, daqueles que até então eram conhecidos (o francês e o americano):

[...] a criação de uma Comissão com o fim especial de elaborar o projeto de Constituição. Para assegurar o equilibrio entre as ideias e propostas que se degladiavam na Câmara, houve o cuidado de fazer a designação dos membros da Comissão de maneira a evitar o predomínio absoluto de alguma corrente de pensamento. Assim, foram designados dois representantes da ala identificada como realista, que eram conservadores, defensores da preservação das instituições tradicionais, e dois representantes dos liberais mais extremados. Além desses, foram designados cinco americanos, entre os quais havia também algumas divergências, pois entre eles havia defensores de uma Confederação Hispanoamericana, enquanto outros propunham que apenas se transformassem as antigas colônias em Províncias, com o mesmo direito de participação no poder central que era assegurado às Províncias do território peninsular (DALLARI, 2014, p. 89).

Por fim, é possível compreendermos que a formação da Constituição de Cádiz e 1812, a partir de um processo conduzido por uma assembleia, composta, por sua vez, por representantes e membros das mais variadas localizações do território espanhol, fosse ele continental, insular ou as dominações hispano-americanas, bem como das mais variadas posições políticas e filosóficas, marcam o caráter revolucionário do constitucionalismo gadatino, o que pode ser compreendido, conforme destacado acima, principalmente, a partir do diálogo

\footnotetext{
${ }^{21}$ Para Dallari, acerca do caráter revolucionário da Constituição de Cádiz em decorrência de seu processo constituinte de formação através de um processo dominado pela necessidade de uma racionalidade dialética, haja vista a presença de inúmeros setores da sociedade espanhola, bem como das regiões e dominações da coroa espanhola, mas que, por terem sido organizados em Assembleia Única, se viram obrigados a estabelecerem um processo de busca por entendimentos e soluções conciliatórias, pois todos os membros das Cortes ali representadas, faziam parte de todas as discussões na formação da Constituição de Cádiz, de modo que par Dallari, portanto, "A forma de organização das Cortes de Cádiz e sua composição já permitiam entrever que havia a possibilidade de avanços consideráveis, embora estivessem presentes representantes das forças e dos interesses tradicionais, resistentes a mudanças muito acentuadas e preocupados com a defesa e manutenção de privilégios seculares. Mas lá estavam também representantes do pensamento liberal mais avançado da época, assim como dos territórios do ultramar dominados pela Espanha, que, mesmo não se alinhando com as propostas mais radicais de independência das colônias, pretendiam que se estabelecessem novas formas de relacionamento, que pusessem fim ao sistema de exploração colonial, que buscava extrair o máximo de riqueza das colônias mantendo seus povos em situação de miséria e escravidão. É particularmente expressivo o pronunciamento de um dos representantes da América nas Cortes de Cádiz, que ficou registrado para a história (2014, p. 88 e 89).
} 
estabelecido entre a Metrópole do Nortee as Colônias do Sul².

\title{
ESPÍRITO LIBERTÁRIO ${ }^{23}$ DA PLURALIDADE ${ }^{24}$ PRESENTE NAS CORTES DE CADIZ E A NECESSIDADE “CONTRADITÓRIA” DA FORMAÇÃO DE UMA NAÇÃO
}

\author{
Conforme se discutiu no ponto acima, o contexto de formação da Constituição de Cádiz de 1812,
} através do processo desencadeado, sobretudo, pelas Assembleias das Cortes de Cádiz, que pode ser compreendido dentro de um cem número de eventos que se desencadeiam desde o fim do séc. XVIII (com a morte de Carlos III) e se estendem até os primeiros anos do Séc. XIX, e que são marcados, em especial, pelos processos de modificações repentinas e autoritárias do Governo Espanhol, principalmente, em relação a figura do

\footnotetext{
${ }^{22}$ Mesmo com todo esse caráter e procedimento de elaboração revolucionários para a época e que foram perpetrados em Cádiz, a Constituição de 1812 ainda guardava muitos aspectos uniformizantes e homogeneizantes, o que poderá, sem melhor compreendido a partir da análise conjunta dos pontos 2 (acima) e 3 (abaixo), sobretudo a partir da construção de uma Nação espanhola (única, exclusiva, homogênea e uniforme). Esses aspectos foram debatidos por Ricardo Sanín Restrepo, em artigo onde o mesmo discute a Constituição de Cádiz como a "antimatéria" da Democracia Latino-americana, chegando a conclusão de que "tradicionalmente a cultura jurídica que impera na América Latina, essencialmente liberal, moderna e, portanto, que imita o Ocidente proclama Cádiz como um lugar inevitável e quase fundacional do constitucionalismo democrático, identifica em sua estrutura jurídica e em seus componentes ideológicos um esquema transcendente que permite aos nossos projetos constituintes criar e afiançar figuras democráticas veneráveis, se vê em Cádiz um rompimento com o passado que assegurou o caminho até a independência e a posterior construção dos modelos jurídicos e políticos que hoje definem a realidade de nossos estados, e por consequência, de nossos povos (2015, p. 413 - tradução nossa). [...] a transferência de Cádiz para a América Latina está atravessada por estratégias de preservação do poder político, continuidade e resistência, mas, sobretudo, por adulterações fabricadas conscientemente para manter a fluidez de um aparato de submissão baseado na retenção da linguagem jurídica por parte de uma elite que continua em um lugar de dominação política, pois cada vez mais está cercada por novas e engenhosas formas de luta pela emancipação da linguagem de define o Direito" (2015, p. 414 - tradução nossa). É, portanto, daí que devemos olhar com cuidado para o espírito libertário de Cádiz, pois, é sabido, que os negros, e consequentemente, $1 / 3$ da população latino-americana, não receberam os direitos civis, não se tornando, assim, cidadãos, o que diminuiu a participação latina em Cádiz, o que acabou trazendo consequências para a relação entre a metrópole e as províncias espanholas latino-americanas. Uma dessas consequências pode ser percebida pelo fato de uma parte das elites Criollas latino-americanas continuar apostando na manutenção dos vínculos políticos, sociais e, até mesmo, culturais, entre a colônia e a metrópole. Esse vínculo, na perspectiva dessas elites, poderia ocorrer através de uma Constituição, desde que essa lhes garantisse o autogoverno de províncias, bem como oferecesse aos latino-americanos uma representação justa nas Cortes e nos demais órgãos do Estado constitucional em ascensão. O que fora usado pelos espanhóis, sobretudo, como forma de debelar os movimentos emancipatórios vindo de além-mar.

${ }^{23}$ A expressão "Espírito Libertário" foi escolhida para ser usada neste ponto do trabalho como um chamado de atenção para a importância da Constituição de Cádiz para a formação de uma "nova" concepção jurídico-política no contexto da época, sobretudo para a península ibérica e todas as suas colônias, bem como pelos constituintes de Cádiz se reconhecerem e serem reconhecidos como liberais. No entanto, compreende-se que a ideia de liberdade e, consequentemente, libertário, historicamente, ainda é símbolo de identidade norte-americana, mas o que, conforme visto, não nos impedirá de nos apropriarmos dessa colocação, pois em Cádiz, com todo esse espírito libertário, a população negra ainda foi eivada de seus direitos civis e políticos, de modo que tal perspectiva, conforme destacado na nota imediatamente acima, foi relevante para a configuração das Cortes de Cádiz e da adoção de suas políticas e diretrizes

${ }^{24}$ A seu turno, a expressão "pluralidade" é usada no contexto de formação da Constituição de Cádiz de 1812, não como a compreendemos atualmente, pois a noção, o conceito de plural, ainda não estava lapidado nos idos do Séc. XIX, sendo uma discussão presente, ainda timidamente, em pleno séc. XXI. Assim, ela deve ser compreendida aqui como uma perspectiva que abrace a ideia da Constituição de Cádiz de 1812 como uma norma mais sensível à efetivação dos direitos ínsitos ao movimento Liberal da época, fato que já marca, por si só, a importância da referida Constituição, sendo que o termo pluralidade voltará a ser debatido no ponto 3 desta pesquisa, momento em que, ao analisar as novas tendências constitucionais latino-americanas, ganhará os contornos ínsitos ao período atual do debate acerca da diversidade.
} 
Rei da Espanha (Carlos IV, Fernando VII ou José I), deu origem, nos termos em que se desenvolverá neste ponto, ao surgimento de um espírito libertário da pluralidade (filosófica, territorial e política) aos espanhóis, que em nossa acepção, é contraditória à ideia de Nação rousseauniana, por essa representar a busca do reconhecimento da unidade do povo.

Assim, num primeiro momento buscaremos compreender a construção desse espírito libertário, a fim de introduzir, ao final (o que será melhor desenvolvido no ponto três abaixo), uma análise de como a busca pela ideia de nação é contraditória, por exemplo, a realização das Cortes de Cádiz, que representaram, na prática, o princípio da condução de uma assembleia constituinte pautada no diálogo entre uma diversidade de opiniões, filosóficas, sociais, políticas, econômicas e culturais, sempre objetivando um consenso, como fundamento de origem para Constituição de Cádiz de 1812.

Contudo, é importante frisarmos nesse aspecto, que mesmo as Cortes de Cádiz, podendo ser vistas como um "embrião" do debate político-democrático-constitucional entre contextos diferentes, não deixou de trazer em suas normas, por exemplo, o reconhecimento da religião católica como a oficial do Estado, o que acabou influenciando a recepção do catolicismo em todo o contexto latino-americano, em como a submissão dos negros, percebidos como seres ainda alijados de direitos civis e políticos, o que provocou a formação de um sistema eleitoral que deu amplos poderes aos representantes espanhóis das Cortes de Cádiz, algo determinante para a relação da metrópole espanhola e suas províncias.

Assim, transpassadas as devidas considerações que deveriam, no pouco espaço de uma pesquisa como esta, faz-se necessário, agora, a partir de então, situar a Constituição de Cádiz e todos os seus desdobramentos antecedentes, com a realidade jurídico constitucional da época de seu surgimento, ou seja, adequá-la ao constitucionalismo de sua época.

A partir de então é possível perceber que a Constituição de Cádiz de 1812 não ficou restrita ao espaço de dominação da coroa espanhola, pois seu modelo único, até então, de formação, fora transmudado para outras realidades, através da adoção de seu Texto, por exemplo, por outros importantes Estados da época, tais como: Portugal, Rússia, Noruega, o Reino das Duas Sićlias (Piemonte e Sardenha), entre outros ${ }^{25}$.

A Constituição de Cádiz ou La Peppa - como costuma ser designada -, portanto, foi fruto do quarto processo constitucional a se desencadear no mundo moderno, ocorrendo depois dos processos revolucionários e dos movimentos constitucionais que deram origem à Constituição dos Estados Unidos (1787), da França

\footnotetext{
${ }^{25}$ Dentre este outros, está presente o Reino do Brasil, que adotou, mesmo que por um dia, a Constituição de Cádiz como sua Constituição em 1821. Para maiores esclarecimentos desse epíteto histórico brasileiro (a primeira Constituição brasileira se deu, antes mesmo da independência do Brasil em face da Coroa Portuguesa - o que viria a ocorrer somente em Setembro de 1822) ver SARNEY, José. La Peppa, Constituição do Brasil - um episódio pouco conhecido da história do Brasil ocorreu em 1821: por um dia La Peppa - a Constituiçao de Cádiz - foi a Constituição do Brasil. Disponível em: <http://www.josesarney.org/blog/la-pepa-
} vol.11, no. 01, Rio de Janeiro, 2018. pp. 39-66 
(1791) e da Suécia (1809), mas, podemos concluir a partir dessas discussões, que fora a primeira em importância e a que mais países influenciou ${ }^{26}$.

Neste contexto, Quijada Mauriño (2008), em debate onde desenvolve uma comparação entre a Constituição de Cádiz, e seu processo construtivo, frente as Constituições Americana e Francesas, parte do princípio de que a grande peculiaridade de Cádiz se deu em decorrência do fato de que nenhuma outra Constituição, existente até então, observou os impulsos revolucionários "do lado de lá do Atlântico" e "abaixo da linha do Equador", propondo uma organização político-administrativa como a assumida em Cádiz.

Para a elaboração da Constituição gadatina de 1812, participaram, efetivamente, como um elemento característicos dos ideais libertários da pluralidade do Reino Espanhol e - o que é muito importante frisarmos em igualdade de condições, a Metrópole, representativa do Norte Global, e seus territórios coloniais de ultramar (América e Filipinas, representativas do Sul Global), que foram convidados a enviar representantes às Cortes Gerais de Cádiz ${ }^{7}$.

Assim, é possível extrair das análises de Quijada Mauriño o fato, por exemplo, da Françą ${ }^{28}$, que assim como qualquer grande potência europeia da época, também possuía inúmeras possessões para além da Europa continental, não aproveitou, fosse em 1791, ou em suas - antes do surgimento da Constituição de Cádiz de 1812 - suas 5 outras oportunidades constituintes de elaboração de Textos Constitucionais, para dar início à retirada da condição de colônias de suas possessões territoriais ultramarinas, insulares, peninsulares ou continentais, mas, a contrário sensu, manteve o status de dependência dessas colônias, frente à Metrópole (2008, p. 18).

\footnotetext{
constituicao-do-brasil/>. Acessado em 08 de Agosto de 2015. A partir de Sarney, é possível percebermos que a expressão La Peppa se deveu ao fato da Constituição gadatina ter sido promulgada no dia de São José (19 de Março).

${ }^{26}$ Segundo Butrón Prida, a Rússia pode ser compreendida como a primeira potência europeia a reconhecer a Constituição de Cádiz, o que se deu em decorrência do tratado hispano-russo de Velikie-Luki, de 20 de julho de 1812, ou seja, poucos meses após a promulgação da Constituição de Cádiz de 1812 (2011, p. 112). De outro lado, recomendamos ver Ditlev Tamm, que analisará, pormenorizadamente, as influências da Constituição de Cádiz sobre a Constituição da Noruega de 1814 (2006, p. 314-319). 21 A Constituição norte-americana foi elaborada em 1787, mas promulgada em 1789 (QUIJADA MAURIÑO, 2008, p. 17). Por fim, é possível compreendermos, a partir de González Hernández (2012, p. 289-296) a grandeza da Constituição de Cádiz, haja vista o mesmo enumerar, vários autores da época, para quem a Constituição de Cádiz de 1812, fora a mais importante Constituição de seu contexto histórico, obtendo, inclusive, o que as constituições francesas e a americana, não conseguiram, uma vocação universal. Para maiores esclarecimentos acerca desses autores, ver GONZÁLEZ HERNÁNDEZ, Esther. Érase una vez... una constitución universal: especial referencia a la proyección en Europa de la Constitución de Cádiz. In.: Revista Historia Constitucional, Madrid, n. 13, p. 283-314, 2012. Disponível em: < http://webcache.googleusercontent.com/search?q=cache:aqxJS67sNckJ:www. historiaconstitucional.cco/index.php/historiaconstitucional/article/download/334/298+\&cd=1\&hl=pt-BR\&ct=clnk\&gl=br>. Acessado em 18 de Março de 2016.

${ }^{27}$ Para Bezerra, o processo desencadeado em Cádiz se deu para as Colônias Espanholas, sobretudo, as hispano-americanas, "[...] ao mesmo tempo em que se negava sua condição de colônias e se afirmava serem "parte essencial e integrante de la monarquía española" (2013, p. 98), concluindo a autora, que "Nem a Constituição de 1776 (um texto escrito pelos representantes das treze colônias que, confederadas, fundaram os Estados Unidos da América, em um claro ato de rebelião que as separava definitivamente da metrópole britânica), nem a Constituição francesa de 1791 fizeram qualquer esforço para abarcar, sob o mesmo conceito de nação e cidadania, os povos (incluídos os índios) de ambos os hemisférios, como o fez a Constituição gaditana” (2013, p. 98).
} 
Contudo, é de se chamar atenção que as fortes características revolucionárias ${ }^{29}$ da Constituição de Cádiz de 1812, que se deveu, principalmente em decorrência de seu processo de elaboração, deu origem a um sentimento de liberdade e de possibilidade do reconhecimento da diversidade, principalmente, num Estado, como o espanhol, composto por inúmeros povos, que fora visto pelas demais monarquias europeias, como uma ameaçada, principalmente, em relação aos princípios liberais que foram desenvolvidos em todo o continente europeu na década dos anos de 1820, que pode ser visto como o germe, a semente, o modelo de todos os seus males, dessas monarquias, de modo que as mesmas não poupariam esforços que desencadearam ataques, constantes e virulentos, à revolução espanhola e a sua Constituição de 1812.

O que pode ser compreendido, por exemplo, pela “vida breve” da Constituição de Cádiz de 1812 (1812$1814^{30}$ ), pois em maio de 1814 o Rei Fernando VII, que para os espanhóis era o Rei de direito, e não José I, de

\footnotetext{
${ }^{28}$ É importante destacarmos ainda, a partir das afirmativas de Quijada Mauriño, que era de se esperar que a Constituição Francesa de 1946 fizesse "[...] desaparecer de sus contenidos el término 'colonia" (2008, p. 18). Ainda hoje, a Constituição Francesa, de 1958 regula Território Franceses Ultramarinos, o que pode ser visto, por exemplo, a partir do art. 74, da referida Constituição gaulesa.

${ }^{29}$ Em relação a essas características revolucionárias da Constituição gadatina, Quijada Mauriño destaca que a Constituição de Cádiz fora decorrente de um processo revolucionário pouco monárquico, mas muito antiaristocrático, de modo que, nestes pontos, se afastam do constitucionalismo revolucionário inglês, mesmo que houvessem, como houve, muitos simpatizantes do liberalismo inglês entre os constituintes das Cortes de Cádiz. Portanto, a referida Constituição fora considerada persona non grata pelos demais governos monárquicos da Europa, haja vista a seu caráter, frisa-se, excessivamente democrático (QUIJADA MAURIÑO, 2008, p. 19). Outra característica importante no distanciamento do constitucionalismo inglês para o espanhol está no fato desse último, e não o primeiro, ser, efetivamente, o berço onde se é possível extrair as primeiras discussões democráticas a partir do estabelecimento de um parlamento, pois no Reino de León, na Espanha, em 1188, segundo Sanchez Albornoz, o Rei Alfonso IX outorgou o que se pode chamar de "a primeira Carta Magna espanhola, bastante anterior à Magna Carta de João Sem Terra (Inglaterra, 1215)", ou seja, La Carta Magna hispana se dirigía a un pueblo que no conocía el régimen feudal, sino una organización beneficiaria y vasallática, a un pueblo cuya aristocracia laica y clerical sólo había logrado una fuerza limitada, a un pueblo articulado en grandes municipios libres, y fue por ello más liberal y democrática que la de Juan Sin Tierra. Los procuradores de las ciudades o villas de los reinos asistieron desde entonces a las Cortes. Y en la segunda mitad del siglo XII no sólo llegaron a dominar en ellas, sino que hicieron de la monarquía castellano-leonesa una monarquía parlamentaria limitada, como ninguna otra en Europa por entonces (1980, p. 73).

${ }^{30}$ É importante destacarmos sobre os vários momentos de aplicação da Constituição de Cádiz, que juntos compreendem a expressão vida breve, que segundo Bezerra, "em $1^{\circ}$ de janeiro de 1820, os militares perpetraram um golpe de Estado (o Pronunciamiento de Riego) em Cabezas de San Juan” (2013, p. 103), por onde o então comandante Rafael de Riego promulgou outra vez como válida para o Estado Espanhol, a Constituição de Cádiz de 1812, de modo que o Rei Fernando VII teve, em decorrência do golpe perpetrado, de aceitar e jurá-la, dando início ao que ficou conhecido como o "Triênio Liberal", que compreendeu o período entre 1820 e 1823. A partir daí, é importante destacar as palavras de Suanzes-Carpegna, para quem "Na realidade, a promulgação desse texto constitucional em 1820 ofereceu uma luz de esperança para os liberais radicais e para os democratas de toda a Europa, relegados ou perseguidos devido à política reacionária que a Santa Aliança havia imposto ao velho continente. Assim, a Constituição de 1812 se converteu, durante o Triênio, em um ponto de referência para todo o movimento liberal e nacionalista da Europa e América, sendo um marco decisivo na história do liberalismo ocidental" (2010, p. 246). Portanto, durante esse período em que a Constituição de Cádiz voltou a designar as orientações do Estado Espanhol, o anteriormente desejado, Rei Fernando VII, ganhou a alcunha de "Rey Felón", ou seja, um Rei traidor e desleal ao povo espanhol, que conspirava contra os interesses desse povo em seu próprio benefício, o que deflagrou, mesmo que não a partir de seu reconhecimento expresso, mas por seus atos, seu rompimento com suas promessas de fidelidade à Constituição de Cádiz de 1812. Neste interim, Fernando VII, buscou auxílio de outros páses para recobrar o governo espanhol, de modo que recorreu, segundo Bezerra (2013, p. 103-104) "[...] à Santa Aliança (Rússia, Áustria, Prússia e França), que, com a ajuda ainda da Inglaterra, veio em seu auxílio para instalar outra vez um governo absolutista, a Década Ominosa (1823-1833), em que não cabia aquela Carta Constitucional de 1812 " e que durou até a morte de Fernando VII, sendo que enquanto se preparava a Constituição posterior, a parir da morte do Rei, outra vez a La Peppa teve mais um curto período de vigência, que se deu entre os anos de 1836 e 1837.
} 
volta da França, resolve dissolver, através de decreto real, as Cortes espanholas, derrogando, assim, a Constituição de Cádiz, o que teve, como consequência, o exílio dos atores liberais do movimento constitucional gadatinno, dando origem a um período de reinado que posteriormente ficaria conhecido como Sexênio Absolutista (18141820) (BEZERRA, 2013, p. 103).

Contudo, o que pode ser mais perceptível de todo o processo de formação da Constituição de Cádiz de 1812, bem como de sua leitura, é a clara e direta proposta libertaria que inaugura em um momento político, social, filosófico e cultural conturbado da história humana, sobretudo da ocidental europeia, se destacando, assim como um texto extremamente inovador para a época.

Essa inovação pode ser percebida pelo fato da Constituição de Cádiz de 1812 promover uma ruptura com uma tradição espanhola de séculos (monarquia absolutista - a partir da unificação dos reinos perpetrada pelo casamento de Fernando de Aragão e Isabel de Castela ${ }^{31}$ - ou reinos absolutos - antes, ainda em um contexto medieval anterior ao pensamento moderno), dando origem a uma Constituição construída a partir de um espírito libertário, por onde o debate de ideias - sobretudo as de cunho liberal, fruto do contexto constitucional da época - pudesse, não só ocorrer, mas ser identificado e compreendido como fundamento de sua criação.

É o que pode ser compreendido, conforme destaca Sanjurjo Conzález, no contexto em que o debate que produziu a Constituição de Cádiz se desenvolveu entre "Liberales unos, realistas otros, unos adeptos al modelo británico, otros al francés, unos más apegados a la tradición nacional, otros más atentos a las novedades europeas" (SANJURJO GONZÁLEZ, 2012, p. 9).

Diante dessas características de rompimento paradigmático e revolucionário da Constituição de Cádiz de 1812, segundo Sánchez Agesta (2011), o deputado Agustín Arguelles, um dos membros da Comissão Constituinte de Cádiz de 1812, se referiu a referida ruptura ${ }^{32}$ como:

Una convulsión universal, simultanea y violenta cual jamás agitó a ningún país civilizado, desencadenando todas las pasiones, aniquiló a un mismo tiempo las autoridades, las leyes y cuantas barreras podían contener el ímpetu de un pueblo enfurecido (ARGUELLES, 1835

\footnotetext{
${ }^{31}$ Esse processo de unificação, nada mais foi, que um processo de sobreposição político-social, cultural e econômica, de um dado modelo, frente a todos os demais. Neste sentido, Anderson (1995, p. 60-83) destaca como a formação do Estado Espanhol, no início da modernidade, pode ser visto como exemplo claro dessa sobreposição político, social e cultural, ou seja, em seu nascimento o Estado espanhol absolutista, surge de um movimento de ascensão de dois reinos (Castela e Aragão) - que se juntam pelo casamento de Isabel (castelhana) e Fernando (aragonês) - e sua sobreposição as demais cidades, reinos ou regiões próximas, tais como: Milão, Navarra, Catalunha, Valência, Galícia, Andaluzia.

32 Acerca desse processo revolucionário e das rupturas perpetradas por Cádiz em 1812, importantes são as palavras de Sáchez Agesta, para quem é necessário deixar claro que referido cenário, que se desdobrou em La Peppa, não se deu a partir do zero, ou seja, não se partiu totalmente do início para a elaboração da Constituição de Cádiz de 1812, é o que pode ser percebido quando analisamos as palavras iniciais do Discurso Preliminar, que dizem que Nada ofrece la Comisión en su proyecto que no se halle consignado del modo más auténtico y solemne en los diferentes cuerpos de la legislación española”. (...). "Las bases de este proyecto han sido para nuestros mayores verdades prácticas, axiomas reconocidos y santificados por la costumbre de muchos siglos (SÁNCHEZ AGESTA, 2011, p. 40).
} 


\author{
apud SÁNCHEZ AGESTA, 2011, p. 30) ${ }^{33}$. \\ A coragem e a determinação ${ }^{34}$ em se construir uma nova ordem jurídico-política dos revolucionários que
} se reuniram em Cádiz, que se embasou em princípios da doutrina clássica dos espanhóis - e, sobretudo, a partir das influências das revoluções inglesa, americana e, em especial, a - portanto, assumiu, formalmente, pela primeira vez na história espanhola, a autoria do próprio destino como Nação e dando o passo decisivo na derrocada do Antigo Regime ainda reinante no contexto espanhol da época, frente ao moderno movimento liberal que se espraiava pelo contexto europeu, desde a revolução inglesa do séc. XVII, mas, sobretudo, a partir dos ideais libertários franceses de 1789.

A ideia de Nação - trazida no Título I, Capítulo I, arts. $1^{\circ}$ ao 4º da Constituição de Cádiz de $1812^{35}$-, contudo, esteio através do qual a Constituição de Cádiz de 1812 se construiu, pode ser compreendida como uma ideia contrária ao espírito que levou os espanhóis às Cortes de Cádiz, pois, por Nação, compreendemos, via de regra, um traço distintivo que aproxima os iguais e afasta os diferentes de um determinado padrão - neste caso, o Ser espanhol - como foi o caso da população negra, cerca de $1 / 3$ dos latino-americanos da época, excluídos dos direitos civis e políticos fincados na supracitada Constituição.

Sobre o papel do desenvolvimento da ideia de Nação na Constituição de Cádiz, Marx e Engels chegam a conclusão de que nenhuma das Constituições que surgiram antes da de Cádiz, cuja Assembleia de discussão e elaboração do texto final contou com a presença de espanhóis de ambos os hemisférios, foi, como a Constituição Gadatina, democraticamente abrangente, ou seja, para eles [...] jamás antes un cuerpo legislativo había reunido a sus miembros de tan distintos lugares del globo o pretendido gobernar territórios tan inmensos en Europa, América y Asia, tal diversidad de razas y tal complejidad de intereses (1998, p. 130-131).

\footnotetext{
${ }^{33}$ Um exemplo, debatido acima, dessa ruptura que significou a Constituição de Cádiz de 1812 com tudo aquilo que, até então o Estado Espanhol conhecia, pode ser percebido na adoção do princípio montesquiano da separação de poderes, de suma importância no contexto revolucionário francês, e que fora explicitamente reconhecido na citada Constituição de 1812, nos artigos 15 ("o poder de fazer as leis reside nas Cortes com o Rei"); 16 ("o poder de fazer executar as leis reside no Rei") e 17 ("o poder de fazer aplicação das leis, tanto nas causas civis, quanto nas criminais, reside nos Tribunais estabelecidos pela lei”), de modo que as atribuições Reais do ausente Rei Fernando VII ficavam reduzidas a dar o devido cumprimento às Normas emanadas das Cortes, representantes máximas da Nação.

${ }^{34}$ Importantes são os comentários do deputado gadatino Antônio Campmany, que, ao comentar a reação do povo como espectador dos debates da assembleia constituinte de Cádiz, percebeu que En cuanto a la opinión que se debe tener del Congreso, contaré un hecho: A los quince días de haberse instalado las Cortes, un caballero inglés, literato, erudito y diplomático, y hombre que ha recorrido todo el mundo, asistió a tres o cuatro sesiones, y salió tan enamorado de la libertad, orden y espíritu verdaderamente nacional que reconoció en ella, que en buen francés dijo delante de los coroneles ingleses y de mí: 'me da vergüenza de ser miembro del Parlamento de Inglaterra [...]' (CAMPMANY apud SOLÍS, 1969, p. 242).

${ }^{35}$ Sob o debate acerca do princípio nacional trazido pela Constituição de Cádiz de 1812, é importante exemplificar, com o próprio texto da Constituição gadatina, que já em seu início, estabelece a Nação como um de seus mais importantes pilares, ou seja, "Titulo I - De la Nación Española y de los Españoles. Capítulo I - De la Nación Española. ARTíCULO 1. La Nación española es la reunión de todos los españoles de ambos hemisferios. ART. 2. La Nación española es libre e independiente, y no es ni puede ser patrimonio de ninguna familia ni persona. ART. 3. La soberanía reside esencialmente en la Nación, y por lo mismo pertenece a ésta exclusivamente el derecho de establecer sus leyes fundamentales. ART. 4. La Nación está obligada a conservar y proteger por leyes sabias y justas la libertad civil, la propiedad y los demás derechos legítimos de todos los individuos que la componen."
} 
É importante destacar, a partir do debate acerca do desenvolvimento do sentimento nacional através da Constituição de Cádiz, que na Idade Média, bem como no período inicial da Idade Moderna no contexto Europeu, a terminologia designada pelo signo "nação" tinha um sentido que pode ser compreendido diferentemente do sentido mais contemporâneo do termo, fruto dos processos revolucionários que ficaram conhecidos como as revoluções burguesas e que embasaram os movimentos constitucionalistas a partir do séc. XVII com o constitucionalismo inglês.

O termo "nação, portanto, era, até então, uma acepção de cunho étnico-histórica que servia para denominar sociedades cujos indivíduos procediam de uma mesma origem e que se integravam, juntamente com outras nações, sob a autoridade de um príncipe capaz de consolidá-las todas em um processo de homogeneização cultural (língua, costumes, religião, etc.) (BEZERRA, 2013, p. 103-104).

A Nação, neste sentido, ainda não era identificada a partir de uma acepção política, o que poderia ser facilmente compreendido pelo fato de que ainda a Soberania do Estado, residir no Monarca, verdadeiro detentor do poder político, e não na Nação, como, a partir do livro O Contrato Social de Rousseau, passou-se a discutir.

Com o advento da Constituição de Cádiz de 1812, houve uma transformação do sentido até então dado a Nação, ou seja, mudou-se de uma concepção "histórica" de nação, uma espécie de nação étnica, conforme visto, que representava um conjunto de relações sociopolíticas que se havia formado ao longo dos séculos de história espanhola, para uma concepção "política" de nação (FERNÁNDEZ SARASOLA, 2006, p. 94).

A concepção política, portanto, representeou a alteração do sentido de nação, de uma situação em que a soberania residia na figura central do monarca, autoridade que detinha todo o poder político do Estado e que, em muitos casos se confundia com o próprio Estado, para um sentido de nação que guarda consigo a soberania do Estado.

Ou seja, deu-se origem a uma nova acepção de nação, nascida nos séculos XVIII e XIX, a partir dos processos revolucionários que ficaram conhecidos como Revoluçôes Burguesas, dentre os quais, conforme se debateu acima, a Constituição de Cádiz de 1812 é um dos mais importantes exemplos, e que derrotaram o antigo regime pautado no absolutismo real, dando origem a um Estado cuja ideia política de nação, e não mais o monarca, era a representação do poder inerente a esse Estado ${ }^{36}$.

Assim, segundo Abascal Conde e Bueno Sánchez, a Nação Espanhola surge como o verdadeiro titular da soberania do Estado Espanhol - o que, como visto acima, pode ser compreendido já nos debates das teorias rousseaunianas -, ou seja, como um sujeito da vida política a partir do processo de construção e do debate por traz

\footnotetext{
${ }^{36}$ Todo esse cenário de transformação paradigmáticas de ideias até então existentes, por exemplo, acerca do que é uma Nação, pode ser compreendida, resumidamente, a partir do momento que "a nação se reorganiza, de nação histórica em nação política; e passa a ser a Nação, e não mais o rei (que, no caso espanhol, havia sido despojado por Napoleão Bonaparte em Bayona), quem se
} 
da Constituição de Cádiz de 1812, pois la nación, por tanto presupone el Estado (y no al revés), un Estado en cuyo seno se produce un proceso por el que sus partes son distinguidas individualmente (y ya no estamentalmente) e igualadas en derechos ante la ley (2008, p. 114).

Neste ponto, há que se ressaltar, também, que todo o processo de onde ser forjou a Nação política espanhola, compreendido através de um período onde as acepções políticas, sociais e filosóficas estavam em Xeque, onde os levantes populares e os conflitos daí decorrentes, contrários, sobretudo, a submissão às imposições francesas através de José I, fizeram com que as Cortes Gerais e Extraordinárias se reunissem em Cádiz e lá produzissem uma nova Constituição, que possui características próprias que, dentre as quais, segundo Abascal e Bueno, uma das mais importantes, está no fato de que todo esse processo, pela primeira vez, contou com o envolvimento dos índios americanos:

España, pues, se transforma en Nación política a partir del rechazo producido contra la invasión napoleónica, siendo además una de las primeras naciones en constituirse en este sentido. Pero la formación de España como Nación política no surge de un vacío político previo, sino que es un proceso que surge en el seno del Antiguo Régimen, en particular, en el seno de una sociedad política imperial sobre la que se constituyó España como 'nación histórica' (es decir, España ya existía políticamente como sociedad política antes de constituirse en Nación política; existía como imperio). Un imperio, además, a través de cuyo desarrollo, enfrentado a otras potencias políticas, no sólo se configura España como nación histórica, sino que también se establecen las primeras redes efectivas de 'globalización', sobre todo a partir de la circunnavegación del globo, por la que sus partes, antes incomunicadas, comienzan a interrelacionarse a través del comercio, la evangelización, la explotación, la guerra, procurando involucrar, para bien o para mal, de un modo efectivo ( $y$ no de manera intencional) a todo el género humano en el proceso civilizatorio. El Imperio español, y la Nación española a él circunscrita (con la participación desde el principio de vascos, catalanes, castellanos, aragoneses, gallegos, andaluces, etc.), si bien no logra gobernar a la 'Humanidad" (según tal proyecto imperial), es capaz con todo de 'envolver' territorios y 'gentes', nos referimos sobre todo a los indios americanos, hasta ese momento completamente desconocidos. Un envolvimiento que en absoluto implicó la desaparición (por aniquilación) de los indios, sino, al contrario, su incorporación de pleno derecho (legislación de Indias) a la 'Nación española' en tanto que súbditos del Rey Católico, poniendo así las bases de lo que supondría su ulterior emancipación (2008, p. 115-116).

Por fim, em que pese a ideia de Nação ganhar novas conotações a partir de Cádiz, conforme debateremos abaixo, a busca pela formação de uma nação espanhola, ao ser debatida quando de sua transição ao contexto hispano-americano, resultou em grandes violações aos direitos de todos aqueles grupos da sociedade que não se enquadravam na moldura, na estética ${ }^{37}$, do ser nacionale que, portanto, foram - ou continuaram a ser

constitui em depositária da soberania. No processo, restaura-se a monarquia espanhola que Napoleão tinha tentado usurpar, mas já em forma de monarquia constitucional" (BEZERRA, 2013, p. 105).

${ }^{37}$ Acerca dos importantes debates sobre a formação moderna de uma estética do ser, podemos perceber que na busca por se tornar potência, verdadeira estética do belo, do correto, daquilo que deva ser seguido, o homem, principalmente, o homem moderno, parte de sua imagem e constrói o seu mundo, dando a ele a sua beleza, o seu modus. Aquilo, que não se enquadrar nesse contexto de beleza formado à imagem do Eu moderno, será construído a golpes de martelo, ou seja, será separado, jogado fora. Sobre a formação dessa estética do $\mathrm{Eu}$ - usada aqui para a compreensão da modernidade - Fabriz destaca a construção de Nietzsche a partir do entendimento de potência e impotência, para quem "[...] o homem constrói o mundo à sua imagem e, em contato com 
- encobertos pelo processo político dos Estados que foram surgindo, por exemplo, no contexto latino-americano da América do Sul.

Assim, é possível concluir que a busca pela construção de uma Nação, ao se analisar os acontecimentos que desencadearam a Constituição de Cádiz de 1812 (algo inerente a cultura europeia ocidental ${ }^{38}$ que sempre está em busca de alcançar uma unificação do todo, a construção de um todo homogêneo) pode ser visto como uma contradição ao processo dialógico, de empoderamento dos diferentes e reconhecimento da necessidade de se dialogar com a diversidade, seja ela política, social, filosófica ou cultural, presente e desenvolvida pelas Cortes de Cádiz.

\section{CONSIDERAÇÕES FINAIS - INICIANDO NOVOS DEBATES A PARTIR DO CONSTITUCIONALISMO PLURINACIONAL LATINO-AMERICANO E DO RESGATE DO ESPÍRITO LIBERTÁRIO DO CONSTITUCIONALISMO DE CÁDIZ}

A partir dos debates traçados nos pontos acima, aqui buscaremos compreender as novas tendências constitucionais latino-americanas que vem sendo chamadas de novo constitucionalismo latino-americano, novo constitucionalismo andino, novo constitucionalismo democrático latino-americano, entre outros muitos nomes, mas que representam transformações, a partir de novos modelos constitucionais dos Estados.

Esses novos modelos podem ser divididos, para melhor compreendermos essas tendências constitucionais das últimas décadas no contexto latino-americano da América do Sul, entre países cujas Constituições perfazem um modelo de Constitucionalismo Multicultural (Canadá (1982); Guatemala (1985); Nicarágua (1987) e Brasil (1988)); entre aqueles países que podem ser compreendidos como de um Constitucionalismo Pluricultural (Colômbia (1991); México (1992); Peru (1993); Bolívia (1994); Argentina (1994) e Venezuela (1999)) e, por fim, entre países cujos textos constitucionais compreendem uma espécie de Constitucionalismo Plurinacional (Equador (2008) e Bolívia (2009) $)^{39}$.

aquilo que é obra de suas mãos, é tomado por um forte impulso estético, dimensionado à beleza de sua existência. Em contrapartida - a golpes de martelo -, tudo aquilo que se torna ameaçador ao seu desejo de potência, que o degenera e o torna impotente, assemelha-se ao antiestético, ao feio, à outra face, não semelhante ao mundo construído, que reflete sua imagem”. (1999, p. 70).

${ }^{38}$ Segundo Herrera Flores, "[... ] a filosofia e a cultura ocidentais apostaram, desde seus primórdios na Grécia, em uma reflexão sobre o puro, o incontaminado, o único, e também num rechaço de tudo que se considerava impuro, contaminado, mesclado, plural” (2009a, p. 85).

${ }^{39}$ Acerca do desenvolvimento dessas etapas, podemos concluir a partir de Raquel Zonia Yrigoyen Fajardo que "o horizonte do constitucionalismo pluralista contemporâneo na América Latina passa por três ciclos: a) o constitucionalismo multicultural (1982 a 1988): composto pelas Constituições do Canadá de 1982, da Guatemala de 1985, Nicarágua de 1987 e do Brasil de 1988. A Constituição do Canadá teria inaugurado o multiculturalismo, pois abre um primeiro reconhecimento de sua herança multicultural e da incorporação dos direitos aborígines; b) o constitucionalismo pluricultural (1989 a 2005): inaugurado pelas Constituições da Colômbia de 1991, México de 1992, Perú de 1993, Bolívia de 1994, Argentina de 1994 e Venezuela de 1999; c) o constitucionalismo plurinacional (2006): inaugurado com o surgimento das Constituições do Equador de 2008 e da Bolívia de 2009” (2011, p. 139-184). De outro lado, mas também analisando os ciclos de formação das novas tendências constitucionais 
Todo esse contexto atual latino-americano de efervescência constitucional das últimas décadas, se dá em uma clara tentativa de romper com a matriz constitucional que nasceu com o fim das primeiras formas de Estados absolutistas - de onde se extrai a Constituição gadatina de 1812, por exemplo - e que se pautou pela busca de uma homogeneização social, política, econômica, ou seja, foi nesse contexto das revoluções dos sécs. XVII, XVIII e XIX que o ideal da afirmação de uma identidade nacional - elemento central da ideia de Nação - fica mais claro, haja vista o fato de um dos pilares desse constitucionalismo clássico da Modernidade ser a monoculturalidade.

A respeito da monoculturalidade presente no ideal de uma Nação como pilar de sustentação de um Estado, Restrepo nos diz que "[...] o elemento concreto que orquestra toda essa multiplicidade é a ordem da Nação, a força do UNO, da unificação e homogeneização" (2015, p. 417 - tradução nossa), o que, de certa forma, ao analisarmos o processo de construção dialógica proposto em Cádiz, é contraditório ${ }^{40}$ ao espírito libertário que conduziu às Cortes de Cádiz em uma abertura, através de uma Assembleia Constituinte, do Estado à realidades para além da Metrópole espanhola.

Neste sentido, também são importantes as palavras de Santos que, percebendo essa característica ínsita aos primeiros modelos constitucional-liberais dos Estados europeus, que nasceram como os primeiros exemplos dos movimentos revolucionários da época, destaca que deles decorrerá - a partir, sobretudo, da colonização da América Latina pelo conquistador e colonizador europeu - o fato de todos os Estados latino-americanos, que surgem posteriormente, nascerem, também, a partir de uma homogeneização (monocultural) de diferentes e diversificadas culturas, fossem elas indígenas ou africanas, ou seja:

Os conceitos fundamentais do constitucionalismo moderno são, assim, os de soberania popular e homogeneidade do povo (é dizer que o povo é homogêneo). Quando se fundou as Nações Unidas, a grande maioria dos países latino-americanos declararam que não tinham minorias étnicas. [...]. Tudo isso para criar um Estado que representasse uma nação e também uma cultura (2009, p. 206 - tradução nossa).

Esse caráter monocultural que se desdobra do exercício da formação de uma Nação, é identificado por Restrepo, ao analisar sua introdução na América Latina, como um agente de violação e segregação dos diferentes, esses que, alijados do debate político e jurídico, são dominados por um padrão cultural, político e social, semelhante - guardadas as devidas proporções - ao que se entabulou como Nação no período das grandes

\footnotetext{
latino-americanas, é importante ressaltarmos as palavras de Wolkmer e Fagundes (2011, p. 403) para quem esse novo cenário foi construído em três momentos, ou seja, “[...] um primeiro ciclo social e descentralizador das Constituições Brasileira (1988) e Colombiana (1991). [...] um segundo ciclo [...] participativo popular e pluralista, em que a representação nuclear desse processo constitucional passa pela Constituição Venezuelana de 1999". E um terceiro ciclo - plurinacional comunitário - "passa a ser representado pelas recentes e vanguardistas Constituições do Equador (2008) e da Bolívia (2009)”. Para maiores esclarecimentos acerca dos movimentos que compreendem o que hoje se chama de novo constitucionalismo latino-americano, ver BRANDÃO, Pedro. O Novo Constitucionalismo Pluralista Latino-Americano. Rio de Janeiro: Lumen Juris, 2015, cap. 1.2, p. 24-34.

${ }^{40}$ Em relação a essa contradição que percebemos entre o movimento revolucionário que desencadeou-se em Cádiz, aberto e dialógico com o Sul Global, e o elemento uniformizante proposto como unificador, a partir dos padrões entabulados pelo Norte Global, extraído da ideia de Nação, importantes são as palavras de Restrepo para quem "[...] o que realmente fazem as Cortes é
} 
Revoluções Burguesas em toda Europa, ou seja, para ele:

[... Na América Latina, a categoria "nação" tem trabalhado como um grande agente de exclusão social e política por excelência, ao invés de haver sido uma ferramenta de emancipação e resistência, ela tem sido uma ferramenta de dominação e destruição da diferença, é na Nação onde se situa a transformação de um projeto colonialista em um projeto de colonialidade. O conceito de Estado-Nação é, quem sabe, o agente mais poderoso durante a estruturação da modernidade ocidental, sua união com a teoria do direito que se autodenomina racional, garantiu sua sacralidade e hermetismo frente a qualquer tipo de oposição e assegurou que seu conteúdo penetrasse e definisse cada uma das formações políticas e jurídicas do mundo moderno (2015, p. 418).

Neste sentido, a modernidade enquanto momento de dominação e culturalização do Mundo a partir da racionalidade europeia padroniza na ideia de Nação, que foi imposta, sobretudo, às Américas e a África, pode ser vista como o período que desencadeou uma sobreposição de um modelo político, social, econômico e cultural, vindo da Europa, à todos os mais longínquos lugares e formas de organização social do planeta.

Esse movimento de segregação e violação da diversidade após a unidade nacional do Estado $\mathrm{Nação}^{41}$ ter sido gestada, promoveu o encobrimento de um pluralismo epistemológico, tão querido e necessário no contexto latino-americano atual, o que acabou legitimando todos os movimentos de violação à cultura, à diferença, à diversidade, movimentos estes que caracterizaram-se pelo cometimento de etnocídios (ALMEIDA, 2012, p. 72), de epistemicídios (SANTOS, 2011, p.87), verdadeiros, nas palavras de Wolkmer, genocídios étnico-cultuais (2008, p. 183).

O novo constitucionalismo latino-americano, portanto, que emerge a partir dos movimentos e lutas sociais nas últimas décadas no contexto latino-americano, cujos ciclos de formação debateu-se, mesmo que perfunctoriamente, nesta pesquisa, objetiva promover um diálogo entre o Eu/Nós e os Eles/Outros, que se dará não por mecanismos de reconhecimento por aquilo que o Eles tem de igual ao Nós, mas por aquilo que o Eles tem em si, ou seja, por aquilo que lhes caracterizam enquanto diferentes (DUSSEL, 2012, p. 17).

Sem que sejamos levianos de dizer que tais movimentos constitucionais têm sua gênese em Cádiz - pois não possuem e não é isso que acreditamos - o movimento do diálogo, entre realidades distintas, mesmo que

inventarem a Nação como lugar de concentração da linguagem, como índice de uma nova verdade que na medida em que o que está por vir existe como o presente que nele está contido” (2015, p. 418 - tradução nossa).

${ }^{41}$ A partir dessas ideias de dominação extraídas do movimento de formação do Estado Nação, sobretudo no contexto latinoamericano, e que podem ser compreendidas como um processo contraditório ocorrido dentro de um cem número de eventos que deram origem a Constituição Espanhola de 1812, Restrepo chega à conclusão de que “[...] o Estado-Nação é a invenção do regime jurídico moderno a partir de quatro falácias: 1. Identidade Nacional [...] Eu me identifico a partir do Outro absoluto que exclui, não como diferente de mim, mas sim como minha negação. [...]. 2. Um modelo universal de cultura que é o europeu-ocidental que demarcará o que está dentro ou fora da verdade política. [...]. 3. A Nação como essência ou motor da história. [...] se constrói a Nação dentro de um historicismo racional, de onde a história é sinônimo da história de todas as nações, onde toda a perfeição humana é, em certo sentido, nacional. O Estado Nação consolida a imagem particular e hegemônica da sociedade moderna, a imagem da vitória da burguesia que adquire assim um caráter histórico e universal. [...]. 4. Através da redução da multiplicidade através da força do UNO, a Nação se converte no veículo do colonialismo. [...] ocorre que o modelo de humanidade está padronizado dentro das dimensões do Estado-Nação e, portanto, o mundo colonial tem que ser seu espelho e sua forma, pois ali está o verdadeiro valor da humanidade cultural, social, econômica e política” (2015, p. 419-420). 
timidamente, está presente no processo de formação das Cortes em Cádiz ${ }^{42}$, mesmo que daí, contraditoriamente, se extraiu a busca pela formação de uma Nação que, como visto, não se adequa ao diálogo, mas, ao contrário, é ínsita ao processo de uniformização do todo a partir de um padrão, construído como a estética do Ser:

É a partir daqui, portanto, que as novas tendências constitucionais latino-americanas, que buscam efetivar uma nova conotação à democracia moderna, provocarão o que Santos (2007, p. 47) denominará de Demodiversidade, ou seja, a construção de uma democracia onde a diversidade cultural ${ }^{43}$ tenha voz e o poder necessário para se fazer presente nas arenas do debate político de seu povo, onde não ser igual é ser normal, e onde o diálogo ${ }^{44}$ possa ser efetivado sem a "pressa de uma decisão".

O novo constitucionalismo latino-americano pode ser visto, nestes termos, como uma válida tentativa, a partir da insurgência do Sul Global, de se vencer os obstáculos à diversidade, pois nesse novo cenário constitucional latino-americano, que é pautado na transformação do Estado, percebemos um resgate do espirito libertário presente nas revoltas que conduziram os espanhóis a Cádiz, e lá, abriram o debate também para o Sul Global.

Por fim, concluímos - sempre provisoriamente - que essa transformação se dará através, não só de uma política de reconhecimento, mas e, principalmente, a partir de um o pluralismo epistemológico ${ }^{45}$, capaz de dar possibilidade ao debate, a nível constitucional, das discussões sobre aquilo que a Constituição do Equador de

\footnotetext{
${ }^{42}$ Sob essa perspectiva, Bethell (2001, p. 231-246) também destaca que os ideais libertários, que já se cristalizavam desde as revoluções precedentes à espanhola, se consubstanciaram em um desejo de emancipação política e social pelas colônias ibéricas frente à metrópole, de modo que fora o contexto de deposição do Rei Fernando VII e da ascensão de José Bonaparte I ao trono espanhol, que agiu como "lenha na fogueira" para o desencadear revolucionário, cujo momento marcante deu origem à Constituiçāo de Cádiz de 1812. Tal perspectiva por ser melhor compreendida em BETHELL, Leslie. (Org.) História da América Latina: da independência a 1870. vol. III. São Paulo: Edusp, 2001, p. 230 e seguintes.

${ }^{43}$ Sobre essa busca por uma nova concepção - ou seja, por um novo sentido ao termo, agora a partir das premissas da interculturalidade - à democracia desencadeado no atual cenário constitucional latino-americano, é importante destacar as palavras de Chivi Vargas sobre o surgimento, neste contexto, dessa perspectiva intercultural da democracia, que reconhece e possibilita uma manifestação política de forma heterogênea, pois "A democracia igualitária é a superação da democracia representativa do século XIX e da participativa do século XX, por uma democracia onde a igualdade material é o centro da atividade estatal, a igualdade formal se acha no baú da história hipócrita do constitucionalismo moderno" (2010, p. 34 - tradução nossa).

${ }^{44}$ Esse modelo de discussão da democracia, pautada pelo diálogo é um processo que se desenvolve na sociedade e vai atingindo o seu exercício paulatinamente, de modo que as novas construções constitucionais Latino-Americanas ainda demorarão algum tempo para surtirem os efeitos pretendidos pelos novos textos constitucionais. Para se entender melhor os fatos que levaram vários países da América Latina reconstruir seus fundamentos constitucionais, principalmente em relação à democracia, buscando uma maior participação de indivíduos que por muito tempo não tiveram acesso às decisões tomadas por seus governos, ver TÁPIA, Luis. Pensando La Democracia Geopolíticamente. La Paz: Muela Del Diablo Editores, 2009. Cap. 4.

${ }^{45}$ Sobre esse pluralismo epistemológico, León Olivé (2009, p. 25) acentua se tratar "de uma disciplina que analisa criticamente as práticas cognitivas, ou seja, aquelas, mediante as quais, se cria, se aplica e se avalia diferentes formas de conhecimento [...]”. Neste sentido, ver também SANTOS, Boaventura de Sousa. Para Além do Pensamento Abissal: das linhas globais a uma ecologia dos saberes. In.: Revista Crítica de Ciências Sociais, n. 78, Outubro de 2007, p. 3-46; TAPIA, Luis. Tiempo, Poiesis y Modelos de Regularidad. In.: Pluralismo Epistemológico. La Paz: Muela del Diablo Editores, 2009.
} 
$2008^{46}$ e da Bolívia de 2009, chamaram, cada qual a seu modo, de "bem viver (sumak kawsay) e dos direitos de pachamama" $^{47}$.

O espírito libertário de Cádiz, portanto, diz respeito ao fato de que no momento de transformação do Estado, pela primeira vez na história do constitucionalismo clássico, os povos coloniais se fizeram presentes, com o mesmo peso em suas opiniões e votos, que os povos da metrópole e, mesmo sendo os representantes das colônias, presentes nas Cortes de Cádiz, em sua maioria, representações das mesmas classes sociais da metrópole, não se deixa de ver aí uma libertação do Sul Global - tímida, é verdade.

Hoje essa busca de uma libertação do Sul Global, vem se desenvolvendo, por exemplo, através do desencobrimento da diversidade latino-americana através dos debates de seu novo cenário constitucional ${ }^{48}$ que

\begin{abstract}
${ }^{46}$ Em atenção à Constituição Equatoriana de 2008, é importante exemplificar, que talvez, a nível mundial, seja o texto normativo que mais prestigia o meio ambiente, ao ponto de reconhecer a necessidade de resguardá-lo como verdadeiro sujeito de direitos, o que se distancia da lógica nacionalista do Estado moderno, que via a natureza como uma propriedade a ser - até as últimas consequências - explorada pelo Homem, pois a referida Constituição da República do Equador de 2008, determina em seu art. 71, que: "La naturaleza o Pacha Mama, donde se reproduce y realiza la vida, tiene derecho a que se respete integralmente su existencia y el mantenimiento y regeneración de sus ciclos vitales, estructura, funciones y procesos evolutivos. Toda persona, comunidad, pueblo o nacionalidad podrá exigir a la autoridad pública el cumplimiento de los derechos de la naturaleza. Para aplicar e interpretar estos derechos se observaran los principios establecidos em la Constitución, em lo que proceda. El Estado incentivará a las personas naturales y jurídicas, y a los colectivos, para que protejan la naturaleza, y promoverá el respeto a todos los elementos que forman um ecossistema".

${ }^{47}$ Sobre essas premissas ínsitas ao novo constitucionalismo latino-americano, Céspedes (2010, p. 10) analisará a necessidade de resgatarmos o outro, o diverso, o diferente, encoberto pela hegemonia uniformizadora, homogeneizante e ideologizante da modernidade colonizadora, a fim de que alcancemos esse bem viver que, segundo ele, trata-se de "[...] recuperar a vivência de nossos povos, recuperar a cultura da vida e recuperar nossa vida em completa harmonia e respeito mútuo com a mãe natureza, com a Pachamama, onde tudo é Vida, onde todos somos uywas, criados da natureza e do cosmos, onde todos somos parte da natureza e não há nada separado, onde o vento, as estrelas, as plantas, as pedras [...] são nossos irmãos, onde a terra é vida em si, bem como o lugar de todos os seres vivos". Para maior aprofundamento ao temos destacados, impossibilitado no presente estudo pelos limites de um artigo, ver CÉSPEDES, David Choquehuanca. Hacia La Reconstrucción Del Vivir Bien. In..: Sumak Kawsay: recuperar el sentido de vida. ALAI, no 452, año XXXIV, II época, Quito, Ecuador, febrero 2010 e MACAS, Luis. Sumak Kawsay: la vida en plenitud. In..: Sumak Kawsay: recuperar el sentido de vida. ALAI, n. 452, año XXXIV, II época, Quito, Ecuador, febrero 2010.

${ }^{48}$ Exemplo desse novo cenário constitucional válido para comparar as constituições de "espirito" gadatino - aquelas cujo eixo ainda é, ou foi, a Nação - com as constituições mais recentes no contexto latino-americano, é o preâmbulo da Constituição Boliviana de 2009, que, em linhas gerais, determina que: "En tiempos inmemoriales se erigieron montañas, se desplazaron ríos, se formaron lagos. Nuestra amazonia, nuestro chaco, nuestro altiplano y nuestros llanos y valles se cubrieron de verdores y flores. Poblamos esta sagrada Madre Tierra con rostros diferentes, y comprendimos desde entonces la pluralidad vigente de todas las cosas y nuestra diversidad como seres y culturas. Así conformamos nuestros pueblos, y jamás comprendimos el racismo hasta que lo sufrimos desde los funestos tiempos de la colonia. El pueblo boliviano, de composición plural, desde la profundidad de la historia, inspirado en las luchas del pasado, en la sublevación indígena anticolonial, en la independencia, en las luchas populares de liberación, en las marchas indígenas, sociales y sindicales, en las guerras del agua y de octubre, en las luchas por la tierra y territorio, $y$ con la memoria de nuestros mártires, construimos un nuevo Estado. Un Estado basado en el respeto e igualdad entre todos, con principios de soberanía, dignidad, complementariedad, solidaridad, armonía y equidad en la distribución y redistribución del producto social, donde predomine la búsqueda del vivir bien; con respeto a la pluralidad económica, social, jurídica, política y cultural de los habitantes de esta tierra; en convivencia colectiva con acceso al agua, trabajo, educación, salud y vivienda para todos. Dejamos en el pasado el Estado colonial, republicano y neoliberal. Asumimos el reto histórico de construir colectivamente el Estado Unitario Social de Derecho Plurinacional Comunitario, que integra y articula los propósitos de avanzar hacia una Bolivia democrática, productiva, portadora e inspiradora de la paz, comprometida con el desarrollo integral y con la libre determinación de los pueblos. Nosotros, mujeres y hombres, a través de la Asamblea Constituyente y con el poder originario del pueblo, manifestamos nuestro compromiso con la unidad e integridad del país. Cumpliendo el mandato de nuestros pueblos, con la fortaleza de nuestra Pachamama y gracias a Dios, refundamos Bolivia. Honor y gloria a los mártires de la gesta constituyente y liberadora, que han
\end{abstract}


ganha força e que, assim como em Cádiz, começa a trazer transtornos para a elite dominante, surgindo a necessidade de se calar - como calaram a Constituição de Cádiz de 1812 - tais movimentos contemporâneos, o que se dá através de alcunhas do tipo "isso bolivarianismo", na tentativa de encobri-los, antes mesmo que amadureçam ou sejam conhecidos.

Analisar, portanto, a Constituição de Cádiz e seu processo de formação e buscar compreender as aproximações (poucas - o espírito libertário embrionário) e os distanciamentos (muitos - a ideia de EstadoNação) das novas tendências constitucionais latino-americanas das últimas décadas, não é impossível, pois em ambos percebemos um sentimento de busca pela transformação do Estado, para que esse passe a ser um instrumento cuja finalidade principal é - e sempre deve ser - realizar o bem comum, que hoje, num sistema de mercado globalizado, é, basicamente, consumir, mas que, a partir das novas constitucionalidades latinas, pode ser visto como a vida em plenitude.

\title{
THE CONSTITUTION OF CÁDIZ OF 1812 AND THE NEW LATIN AMERICAN CONSTITUTIONALISM - A BRIEF ANALYSIS OF LATIN AMERICAN CONSTITUTIONALISM IN ITS ORIGINS
}

\begin{abstract}
This research is developed in order to analyze the training context of the Cadiz Constitution of 1812, in its most elementary aspects, such as the process of debate through the Cortes of Cadiz, as well as the need to format an idea political nation, underpinning by which the new Spanish state would be raised from an approach (where possible) or distance (where not possible) with the new Latin American constitutional trends emerging in recent decades in the political context, social, economic and cultural Latin America, in order to identify these scenarios a libertarian spirit of diversity, through a dialogic process, to be developed between the Self and the Other, in the formation of a more plural society, more supportive especially in times like the present, in which morality, civility of human beings are put aside.
\end{abstract}

Keywords: Constitution of Cadiz; New Constitutionalism Latin American; Spirit Libertarian; Nation-State; Global South.

\footnotetext{
hecho posible esta nueva historia”. Além disso, é importante ressaltar, que outras diferenças que buscam suprir o aspecto monocultural e homogeneizante da Constituição de Cádiz de 1812 e daquelas daí resultantes, embasadas em uma ideia de Nação uniformizada a partir de uma única identidade, podem ser visualizadas, por exemplo, na estrutura organizacional do Estado boliviano a partir da Constituição de 2009, o que pode ser percebido no momento em que se destacam, a partir da mencionada Constituição, autonomias distintas e complementares dentro do Estado boliviano, são elas: a departamental: arts. 277-279; a regional: arts. 280-282; a municipal: arts. 283 e 284 e, ao fim, a indígena originária campesina: arts. 289-297. Assim também é o fato do Estado Plurinacional boliviano estabelecer, através da Constituição de 2009, que a educação deverá ser, nos termos de seu art. 78, "I - La educación será unitaria, fiscal, publica, universal, democrática, participativa, comunitaria, descolonizadora y de calidad. II - La educación sera intracultural, intercultural y plurilíngüe en todo el sistema educativo. III - El sitema educativo se fundamentará en una educación abierta, científica, técnica y tecnológica, productiva, territorial, teórica y práctica, libertadora y revolucionária”
} 


\section{REFERENCIAS}

ABASCAL CONDE, Santiago; BUENO SÁNCHEZ, Gustavo. En defensa de España: razones para el patriotismo español. Madrid: Encuentro, 2008. Disponível em: <http://eprints.ucm.es/21632/1/Manifiesto_en_defensa_de_Espa\%C3\%Bla.pdf >.Acessado em 30 de nov. de 2015.

ALMEIDA, Lúcio Flávio Rodrigues de. Lutas sociais e questões nacionais na América Latina: algumas reflexões. Disponível em: <http://www.pucsp. br/neils/downloads/v17_18_lucio.pdf >. Acessado em: 20 de ago. de 2015.

ANDERSON, Perry. Linhagens do Estado Absolutista. 3aed. trad. por BASTOS, Suely e BRITTO, Paulo Henrique. Tatuapé: Editora Brasiliense, 1995.

BETHELL, Leslie. (Org.) História da América Latina: da independência a 1870. vol. III. São Paulo: Edusp, 2001.

BEZERRA, Helga Maria Saboia. A Constituição de Cádiz de 1812. In.: Revista de Informação Legislativa. Ano 50, N. 198, abr./jun. 2013. Disponível em: <http://www2. senadoleg.br/bdsf/bitstream/handle/id/496957/000983396.pdf?sequence=1>. Acessado em 12 de set. de 2015.

BRANDÃO, Pedro. O Novo Constitucionalismo Pluralista Latino-Americano. Rio de Janeiro: Lumen Juris, 2015.

BUTRÓN PRIDA, Gonzalo. Guerra, nación y constitución: la proyección europea de la guerra de independencia española. In.: Cuadernos Dieciochistas, Madrid, n. 12, p. 101-122, 2011. Disponível em: $<$ http://rodin.uca.es/xmlui/bitstream/handle/

10498/17521/Cuadernos\%20Dieciochistas\%20Butr\%C3\%B3n.pdf?sequence $=1$ \&isAllowed=y>. Acessado em 02 de fev. de 2016.

CÉSPEDES, David Choquehuanca. Hacia La Reconstrucción Del Vivir Bien. In.: Sumak Kawsay: recuperar el sentido de vida. ALAI, n. 452, año XXXIV, II época, Quito, Ecuador, febrero 2010.

CHIVI VARGAS, Idón M. Nueva Constitución y Desarrollo Normativo. In.: Agência Latinoamericana de Información América en Movimiento. Ano 2010. Disponível em: <http://alainet.org/active/35872\&lang=es>. Acesso em: 16 de ago. de 2015.

COHEN, Fernando e BUENO, Gustavo. Muy Interesante. Madrid, feb. 2008. Disponível em: $<$ http:/ /www.muyinteresante.es/gustavo-bueno>. Acesso em 24 de Março de 2016.

DALLARI, Dalmo de Abreu. A Constituição de Cádiz: valor histórico e atual. In..: Revista de Estudios Brasileños. v. 1.n. $1.2^{\circ}$ sem. de 2014.

DUSSEL, Henrique. 1492 El Encubrimiento Del Otro: hacia El origen del "mito de La Modernidad. La Paz: Plural Editores, 1994.

Ética da libertação: na idade da globalização e da exclusão. 4aed. Petrópolis: Editora Vozes, 2012.

FERNÁNDEZ SARASOLA, Ignacio. La Primera Constitución Española: el Estatuto de Bayona. Revista de Derecho. Bogotá, N. 26, Ano 2006, p. 89-109. Disponível em: <http://www.redalyc.org/html/851/85102605/>. 
Acessado em 29 de nov. de 2015.

Los Constituyentes Asturianos en las Cortes de Cádiz: antología de discursos. Gijón: Trea, 2012.

GONZÁLEZ HERNÁNDEZ, Esther. Érase una vez... una constitución universal: especial referencia a la proyección en Europa de la Constitución de Cádiz. In.: Revista Historia Constitucional, Madrid, n. 13, p. 283-314, 2012. Disponível em: <http://webcache.googleusercontent.com/search?q=cache:aqxJS67sNckJ:www. historiaconstitucional.cco/index.php/historiaconstitucional/article/download/334/298+\&cd=1\&hl=ptBR\&ct=clnk\&gl=br $>$. Acessado em 18 de mar. de 2016.

HERRERA FLORES, Joaquín. A (re) Invenção dos Direitos Humanos. Florianópolis: Fundação Boiteux, 2009a. Teoria crítica dos direitos humanos: os direitos humanos como produtos culturais. Rio de Janeiro: Lumen Juris, 2009b.

KROHLING, Aloísio. Dialética e Direitos Humanos - múltiplo dialético: da Grécia à Contemporaneidade. Curitiba: Juruá Editora, 2014.

MACAS, Luis. Sumak Kawsay: la vida en plenitud. In.: Sumak Kawsay: recuperar el sentido de vida. ALAI, nº 452, año XXXIV, II época, Quito, Ecuador, febrero 2010.

MARX, Karl e ENGELS, Friedrich. Escritos sobre España: extractos de 1854. Madrid: Trotta, 1998.

OLIVÉ, León. Por una Auténtica Interculturalidad Basada em El Reconocimiento de La Pluralidad Epistemológica. In..: Pluralismo Epistemológico. La Paz: Mueladel Diablo Editores, 2009.

PÉREZ GARZÓN, Juan Sisinio. Cortes y constitución en Cádiz: la revolución española (1808-1814). Madrid: Anaya, 2012. Disponível em: <https://dialnet.unirioja.es/servlet/libro?codigo=568356>. Acessado em 21 de out. de 2015 .

QUIJADA MAURIÑO, Mónica. Una constitución singular: la carta gaditana en perspectiva comparada. In.: Revista de Índias, Madrid, v. 68, n. 242, 2008, p. 15-38. Disponível em: <http://www.red-redial.net/revistarevista,de,indias-33-2008-68-242.html>. Acessado em 29 de set. de 2015.

RESTREPO, Ricardo Sanín. La Constitución de Cádiz o La Antimateria de La Democrcia Latinoamericana. In: BALDI, César Augusto (coord.). Aprender Desde o Sul - novas constitucionalidades, pluralismo jurídico e plurinacionalidade - aprendendo desde o sul. Belo Horizonte: Fórum, 2015.

RIBAS, Pedro. Estudio Preliminar: In: MARX, Karl e ENGELS, Friedrich. Escritos sobre España: extractos de 1854. Madrid: Trotta, 1998.

SÁNCHEZ AGESTA, Luis. Introducción. In: ARGÜELLES, Agustín. Discurso preliminar a la Constitución de 1812. Madrid: Centro de Estudios Políticos y Constitucionales, 2011. Disponível em: <http://www.cepc.gob.es/docs/actividades-bicentenario1812/discuprelicons 1812.pdf?sfvrsn=2>. Acessado em 12 de fev. de 2016.

SÁNCHEZ-ALBORNOZ, Claudio. Ensayos sobre historia de España. Madrid: Siglo Veintiún, 1980.

SÁNCHEZ-ARCILLA BERNAL, José. La experiencia constitucional gaditana y la constitución portuguesa de 1822. Cuadernos de Historia Contemporánea, Madrid, 2002. Vol. 24, p. 105-143. Disponível em: 
$<$ https://www.researchgate.

net/publication/27588787_La_experiencia_constitucional_gaditana_y_la_Constitucion_ portuguesa_de_1822> Acessado em 05 de jan. de 2016.

SANJURJO GONZÁLEZ, Pedro. Prefacio. In.: FERNÁNDEZ SARASOLA, Ignacio. Los constituyentes asturianos en las Cortes de Cádiz: antología de discursos. Gijón: Trea, 2012.

SARNEY, José. La Peppa, Constituição do Brasil - um episódio pouco conhecido da história do Brasil ocorreu em 1821: por um dia La Peppa - a Constituiçao de Cádiz - foi a Constituição do Brasil. Disponível em: $<$ http://www.josesarney.org/blog/la-pepa-constituicao-do-brasil/>. Acessado em 08 de ago. de 2015.

SANTOS, Boaventura de Sousa. Para Além do Pensamento Abissal: das linhas globais a uma ecologia dos saberes. In.: Revista Crítica de Ciências Sociais, n. 78, out. de 2007, p. 3-46.

A Gramática do Tempo: para uma nova cultura política. 3aed. São Paulo: Cortez Editora, 2011.

Pensar El Estado Y La Sociedad: desafios actuales. Buenos Aires: Waldhuter Editores. 2009.

TÁPIA, Luis. Pensando La Democracia Geopolíticamente. La Paz: Muela Del Diablo Editores, 2009.

Tiempo, Poiesis y Modelos de Regularidad. In: Pluralismo Epistemológico. La Paz: Muela del Diablo Editores, 2009a.

SOLÍS, Ramón. El Cádiz de las Cortes: la vida en la ciudad en los años 1810 a 1813. Madrid: Alianza, 1969.

SUANZES-CARPEGNA, Joaquín Varela. O constitucionalismo espanhol e português durante a primeira metade do século XIX: um estudo comparado. In.: Revista Historia Constitucional, Madrid, n. 11, p. 237-274, 2010. Disponível em: <http://webcache.googleusercontent.com/search?q=cache:QPgsQKAqgaQJ:www. seseminariomartinezmari.com/ojs/index.php/historiaconstitucional/article/download/270/238+\&cd=1\&hl=p $\mathrm{t}-\mathrm{BR} \& \mathrm{ct}=\mathrm{clnk} \& \mathrm{gl}=\mathrm{br}>$. Acessado em 03 de dez. de 2015.

TAMM, Ditlev. Cádiz 1812 y Eidsvoll 1814. In.: Revista Historia Constitucional, Madrid, n. 7, p. 314-319, 2006. Disponível em: <https://dialnet. unirioja.es/servlet/articulo?codigo=2060238>. Acessado em 23 de nov. de 2015.

WOLKMER, Antonio Carlos e FAGUNDES, Lucas Machado. Tendências Contemporâneas do Constitucionalismo Latino-Americano: o estado plurinacional e pluralismo jurídico. In.: Revista Pensar. Fortaleza, jul./dez.v. 16.n.2.p. 371-408.2011.

YRIGOYEN FAJARDO, Raquel Zonia. El Horizonte de Constitucionalismo Pluralista: del multiculturalismo a la descolonización. In: GARAVITO, César Roberto (Comp.). El Derecho en América Latina: un mapa para el pensamiento jurídico del siglo XXI. Buenos Aires: Siglo Veintiuno, 2011, p. 139-184.

Trabalho enviado em 05 de maio de 2016.

Aceito em 31 de agosto de 2016. 